\title{
Estimation of the moment magnitude and local site effects of a postulated Late Bronze Age earthquake: Mycenaean citadels of Tiryns and Midea, Greece
}

\author{
Hector R. Hinojosa-Prieto ${ }^{1,2}$ \\ (1) Earthquake Geology and Archaeoseismology, Institute for Geology and Mineralogy, Cologne University, \\ Bensberg Seismological Station, Vinzenz-Pallotti-Str. 26, 51429, Bergisch Gladbach, Germany \\ (2) Cordillera Geo-Services, LLC 1723 Warwick Way, Cedar Park, Texas 78613, USA
}

Article history: received March 3, 2018; accepted January 10, 2020

\begin{abstract}
Previously interpreted archaeological and geological field data from the Argive Basin, Greece, have been used to hypothesized that the nearby Late Bronze Age Mycenaean citadels of Tiryns and Midea, which settled on bedrock, might record synchronized co-seismic structural damage due to earthquake ground-shaking at ca. 1190 BCE, the end of the Mycenaean palatial period. However, from a quantitative archaeoseismological perspective, this hypothesis has flaws: (a) it overlooks that several structures excavated in the undeformed Holocene sediments lack evidence of coseismic structural damage and damage is only documented for sturdier structures within the citadels, $(b)$ it leaves unexplained the moment magnitude of the 'causative' surface-rupturing earthquake, and $(c)$ disregards the role of local site effects on surface ground-motion. The plausibility of the previously proposed earthquake hypothesis is tested by estimating the earthquake magnitude of the alleged ancient earthquake and its local site effects at and around the citadels, assuming that the earthquake truly occurred. A retrospective geotechnical site microzonation coupled with the calculation of seismic amplification factors, surface ground-motions, and earthquake intensity account for the local site effects assessment. The present numerical modeling results indicate that the citadels and contemporaneous adjacent structures of the peasants had a lower and higher seismic hazard, respectively. Seismic amplification factors, earthquake-induced ground shaking, and seismic intensity are indeed lower for Tiryns than for Midea. Therefore, these results refute the idea of seismically induced destruction of the citadels and challenge the plausibility of the earthquake hypothesis. The previously archaeologically documented destruction patterns unlikely represent physical evidence of co-seismic damage by the archaeologically proposed earthquake. Other explanations ought to be sought to elucidate the interpreted destruction pattern seen in these Mycenaean centers.
\end{abstract}

Keywords: Forward modeling, Tiryns, Midea, Late Bronze Age earthquakes, local site effects, Archaeoseismology, Mycenae fault. 


\section{Hector R. Hinojosa-Prieto}

\section{Introduction}

The Mycenaean culture existed during the Late Bronze Age (LBA) (from before 1600 to ca. 1050 BCE). In the Argive Basin (AB) of eastern Peloponnese, Greece, which was one of the core areas, most of its centers settled on outcropping bedrock ridges [Demakopoulou, 1995; Maran, 2010]. These Mycenaean strongholds include the nearby citadels of Tiryns and Midea, located within a $\leqslant 150 \mathrm{~km}$ epicentral distance from moderate to great earthquake sources (Figure 1). Peripheral fault-bounded sedimentary basins in the Peloponnese (Figure 1) show much lower crustal seismic activity than distal sources; however, seismicity includes earthquakes down to $80 \mathrm{~km}$ deep in the subducting African plate [Hatzfeld et al., 1993].

Vintage archaeological excavation data [Kilian, 1978, 1980, 1996; Åström and Demakopoulou, 1996] together with geological [Papanastassiou et al., 1993; Zangger, 1993] and geomorphological field observations [Gaki-Papanastassiou et al., 1996; Maroukian et al., 1996] have led to suggest that Tiryns and Midea might record (in archaeological terms of relative chronology) synchronous co-seismic structural damage due to the occurrence of a local earthquake during the end of the palatial period, the size and strength of which remain unestimated. In his posthumously published paper of 1996, Kilian mentioned the possibility of several such earthquakes deduced from certain features in the destruction layers of the Citadel, archaeologically dated to Late Helladic (LH) IIIB Early (ca. 1300-1260 BCE), LH IIIB Middle (ca. 1250-1240 BCE), and LH IIIB Final (ca. 1200-1190 BCE), might have damaged palatial buildings at Tiryns [Kilian, 1978, 1980, 1996]. The destruction layers feature tilted and curved walls and foundations, some containing fallen pottery and human skeletons presumably killed by collapsing buildings [Kilian, 1996]. At Midea, located $\sim 8 \mathrm{~km}$ north-east from Tiryns, the earthquake at the end of LH IIIB2 is also thought to have caused structural damage to several buildings and the Cyclopean walls currently found in a somewhat collapsed position [Papanastassiou et al., 1993; Åström and Demakopoulou, 1996]. Table 1 summarizes the previously archaeologically interpreted evidence of destruction layers at these citadels. Recent quantitative archaeoseismic studies using different approaches [Hinzen et al., 2015, 2016, 2018; Hinojosa-Prieto, 2016], in the framework of the HERACLES project, collectively refute the earthquake hypothesis. Moreover, a reactivation during ca. 1190 BCE of the so-called nearby Mycenae fault is traditionally attributed to the rupture of a local earthquake, on the basis of field geologic fault data [Papanastassiou et al., 1993] and geomorphologic field observations [Gaki-Papanastassiou et al., 1996; Maroukian et al., 1996]. However, both the source parameters (i.e., moment magnitude, seismic moment, and earthquake stress-drop) of this particular presumed earthquake and its probable local site effects have remained unestimated since the rise of the earthquake hypothesis, which are the goals of the present quantitative archaeoseismic investigation.

\begin{tabular}{|c|c|c|c|}
\hline $\begin{array}{l}\text { Mycenaean } \\
\text { citadel }\end{array}$ & $\begin{array}{l}\text { Archaeologically dated } \\
\text { destruction layer(s) }\end{array}$ & $\begin{array}{l}\text { Archaeologically interpreted } \\
\text { evidence }\end{array}$ & Reference \\
\hline Tiryns & $\begin{array}{l}\text { at } c a .1250 \text { BCE, at } c a \text {. } \\
1200 / 1190 \text { BCE, and in later } \\
12^{\text {th }} \text { century BCE (Late } \\
\text { Helladic IIIC Advanced) }\end{array}$ & $\begin{array}{l}\text { Tilted and curved walls and } \\
\text { foundations, building repair after } \\
\text { destruction; fallen and broken clay } \\
\text { figurines, vessels, bowls, tiles; human } \\
\text { skeletons of a woman and child } \\
\text { presumably killed by a collapsing } \\
\text { building; fires. Differential } \\
\text { subsidence in coastal Argive Basin. }\end{array}$ & $\begin{array}{l}\text { Kilian [1988, 1996], } \\
\text { Zangger [1993] }\end{array}$ \\
\hline Midea & $\begin{array}{l}\text { end of Late Helladic } \\
\text { IIIB2 period } \\
\text { (ca. 1200/1190 BCE) }\end{array}$ & $\begin{array}{l}\text { Skeleton of a young girl with skull and } \\
\text { backbone smashed under fallen rocks; } \\
\text { fire/ash layer, collapsed, tilted and } \\
\text { curved walls, collapsed buildings; } \\
\text { postulated abandonment of citadel; } \\
\text { broken pottery assemblages; objects } \\
\text { such as pottery, clay figurines, stone } \\
\text { and bronze tools, and gold bead found } \\
\text { in fill presumably fallen from the } \\
\text { upper floor. }\end{array}$ & $\begin{array}{l}\text { Åström and } \\
\text { Demakopoulou [1996]; } \\
\text { Demakopoulou [2012] }\end{array}$ \\
\hline
\end{tabular}

Table 1. Archaeologically proposed earthquake strata at Tiryns and Midea [after Hinojosa-Prieto, 2016]. 


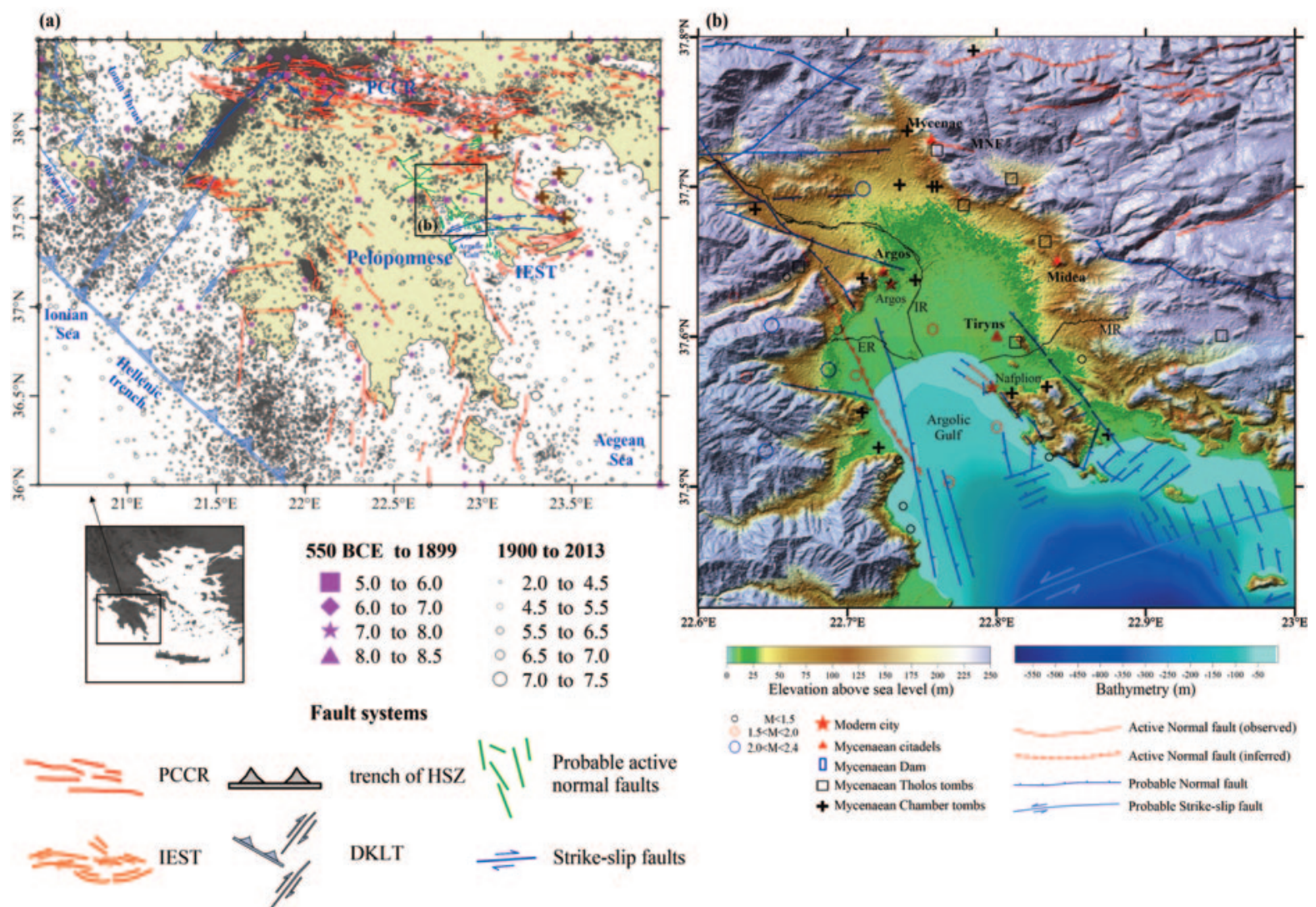

Figure 1. (a) Seismicity of the Peloponnese from 550 BCE to 1899 (taken from The University of Athens, Greece (UOA) catalog) and from 1900 to 2013 (from Aristotle University of Thessaloniki, Greece catalog). PCCR: Patras-Corinth Continental Rift; IEST: Iria-Epidaurus Sinistral Fault system; active normal and strike-slip faults: red and blue line, respectively; probable active normal fault: green line; brown crosses correspond to active volcanoes. (b) Digital Elevation Model of the Argive Basin, Greece. Neotectonic setting of the Argive Basin-Argolic Gulf sedimentary basin. Instrumental seismicity from Hatzfeld et al. [1989], UOA catalog, and Hinojosa-Prieto [2016]. Fault traces from Papastamatiou et al. [1960], Tataris et al. [1970], van Andel et al. [1993], Papanikolaou et al. [1994], Hatzfeld et al. [1999], and Georgiou and Galanakis [2010]. Terrain model from the Shuttle Radar Topography Mission (SRTM) 3 arc-second resolution. Bathymetry model from the National Oceanic Atmospheric Administration (NOAA) Geodas data. MNF: Mycenae normal fault; IR: Inachos River; ER: Erasinos River; MR: Manessi River.

\section{Geologic setting and site description}

The $\mathrm{AB}$ is the onshore continuation of the Pliocene-Pleistocene sediment wedge of the Argolic Gulf (AG) and together form a Late Neogene-Quaternary half-graben opening to the Aegean Sea [van Andel et al., 1990, 1993] (Figure 1). The AB's bedrock is an assemblage of moderately to weathered and fractured Upper Triassic to Upper Paleogene mesoautochthonous karstic carbonates ( $100 \mathrm{~m}$ thick) thrusted onto post-Early Eocene flysch deposits (<200 m thick) and minor shale [Hinojosa-Prieto and Hinzen, 2015 and references therein] (Figure 2). The Upper Pliocene to Quaternary clastic sequence that fills up the AB is in angular unconformity with the bedrock [HinojosaPrieto and Hinzen, 2015]. Following, the geological maps of Nafplion [Tatris et al., 1960] and Argos [Papastamatiou et al., 1970], the Upper Pliocene deposits are comprised by a lower and an upper member. Sand marls, sandstones and conglomerates make up the lower member [Tataris et al., 1960]. Marls, sandy marls, pebbly and coarse conglomerates, and marly sandstone-conglomerates make up the upper member [Tataris et al., 1960; Papastamatiou et al., 1970]. The Quaternary sediments include a basal well-consolidated Upper Pleistocene package of marine clays, silts to sands and gravels (of variable thickness), in turn, covered by Holocene unconsolidated marsh to fluviotorrential deposits composed of chaotically interbedded and unconsolidated clays, silts, sandy-silts, sandy-clays, 


\section{Hector R. Hinojosa-Prieto}

sandy-gravels, subordinate pebbly gravel-silts and lesser silty-sands [Zangger, 1993]. The Holocene materials in the western and central $\mathrm{AB}$ are mainly a mix of unconsolidated clays, silty-clays, clayey-silt, fine-sands, and sandygravels. The sediments in the east are poorly consolidated alluvial fan deposits composed of marls, sandy-marls, very-coarse sands and very-coarse gravels and pebbly to coarse conglomerates. The soils around Tiryns and Midea classify as cohesive soils and granular soils, respectively, and are still a good representation of the ancient soils around Mycenaean Tiryns and Midea [cf. Zangger, 1993]. Numerous bore wells in the AB were drilled in the 1960's and 1970's for agricultural purposes, but only few reached the local bedrock. Their lithology logs indicate a heterogeneous stratigraphy [Hinojosa-Prieto, 2016] and coupled with recent geophysical surveys [Karastathis et al., 2010; Hinojosa-Prieto and Hinzen, 2015; Hinzen et al., 2018] reveal an uneven bedrock topography.

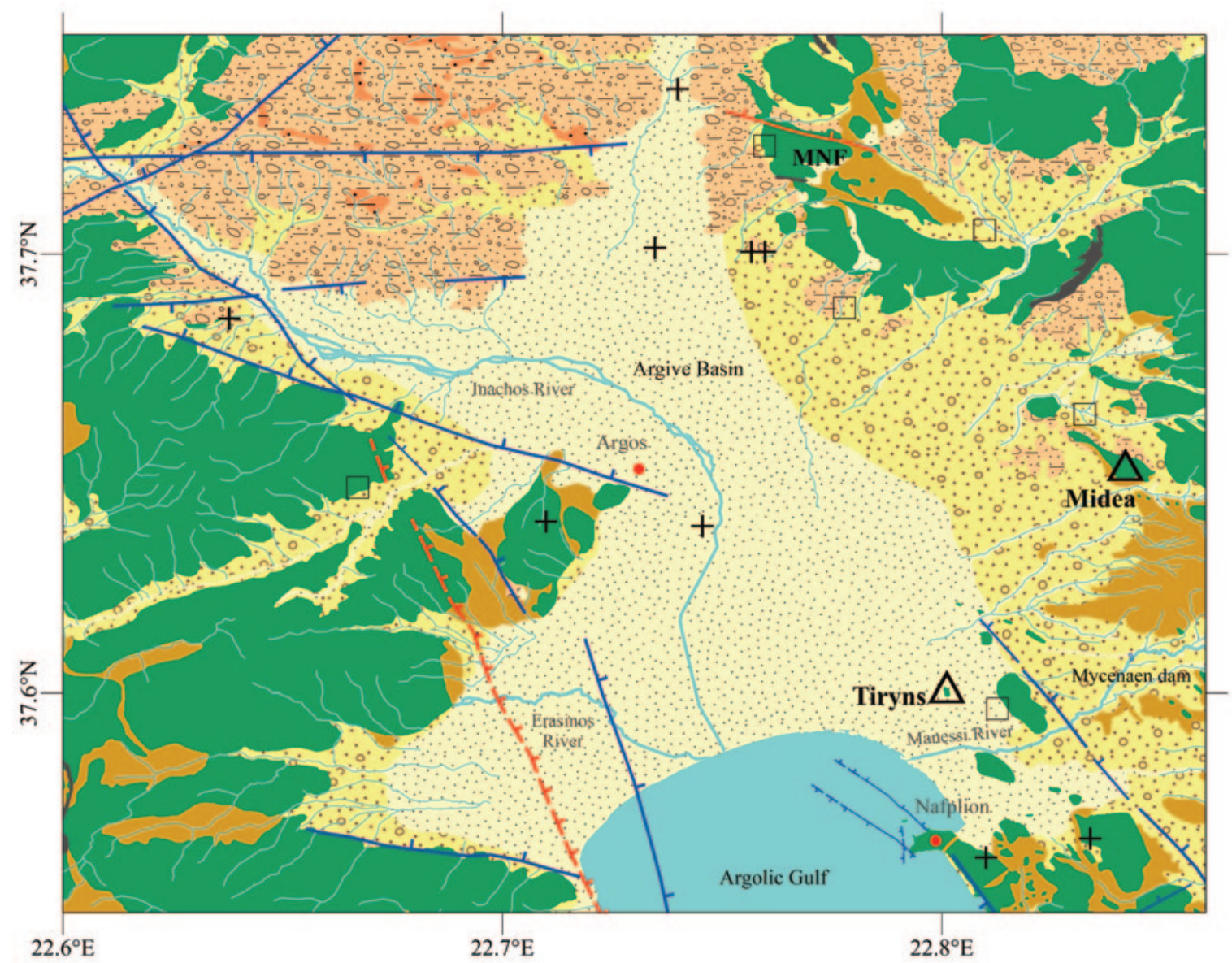

\section{Argive Basin sediments}

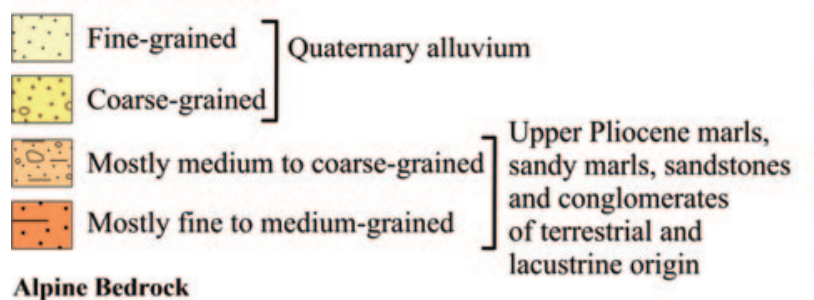

Alpine Bedrock

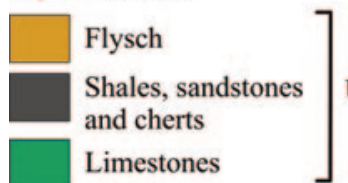

Upper Triassic - Early Eocene
- City or village $\Delta$ Mycenaean citadel Mycenaean Dam

+ Mycenaean Chamber tomb $\square$ Mycenaean Tholos tomb

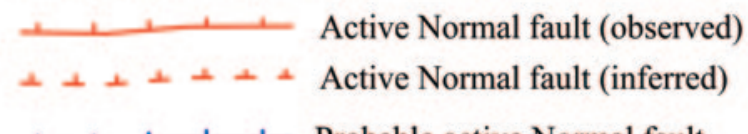

Scale: $2 \mathrm{~km}$

Figure 2. (a) Geologic map of the Argive Basin, Greece [after Hinojosa-Prieto, 2016]. MNF: Mycenae normal fault. 
The citadels of Tiryns and Midea were built on outcropping bedrock ridges rising above the Holocene soils at an elevation of 28 and $268 \mathrm{~m}$ (a.s.1.), respectively (Figures 1 and 2). The Tiryns hill comprises a ca. 97-93 Ma, thickly to very-thickly bedded, tectonically fractured and karstified limestone at angular unconformity with the overlying cohesive soils [Hinojosa-Prieto and Hinzen, 2015]. The Midea ridge comprises a weathered, fractured, karstified, crystalline ca. 97-56 Ma limestone thrusted against weathered post-Early Eocene (> ca. $48 \mathrm{Ma}$ ) flysch deposits [Hinojosa-Prieto, 2016]. Figure 3 shows the stratigraphy of the Tiryns and Midea archaeological sites. Archaeological excavations at the Tiryns [Schliemann, 1886; Kilian, 1978, 1980, 1988; Maran, 2004, 2010] and Midea citadels [Åström and Demakopoulou, 1996; Walberg, 2001] have revealed Mycenaean architecture (Figure 4). The Cyclopean style fortification wall circuit of Tiryns is about $750 \mathrm{~m}$ long, nearly $7 \mathrm{~m}$ thick, currently preserved at a maximum height of $9.9 \mathrm{~m}$, and encloses an area of nearly 18,500 $\mathrm{m}^{2}$ [Papadimitriou, 2001].

(a) Tiryns

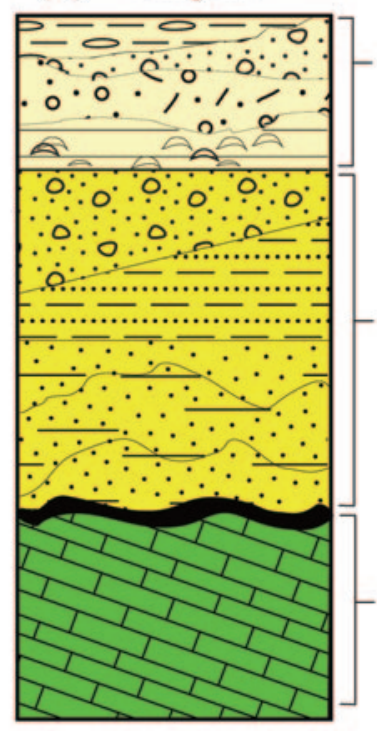

Siliciclastic deposits composed of silt-fine gravels, sandy to pebbly alluvium and coarse colluvuim and overbank loams; Holocene

Terrestrial-Marine siliciclastic deposits composed of pebbly-to-coarse alluvium, well-consolidated clays and silts (red paleosoils); Late Pleistocene

\section{Angular Unconformity}

Limestone: moderately south-dipping, fractured, karstified light gray, unfossiliferous to poorly-fossiliferous, thickly to very-thickly and well-bedded; Cenomanian (ca. 97-93 Ma)

\section{Cohesive} soils (b) Midea

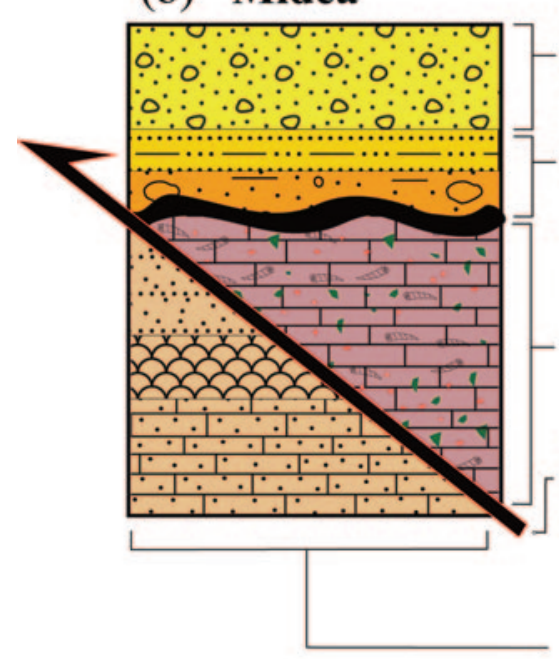

Conglomerates (make up terraces),

alluvial fans, torrential pebbly-coarse conglomerates, stream deposits; Quaternary age

Marls, sandy marls, pebbly and coarse conglomerates;

Sandy marls, sandstones and conglomerates;

Upper Pliocene-Pleistocene age

\section{Angular Unconformity}

Mesoautochtonous Carbonate Sequence: neritic limestones, coarse polymictic talus-breccias rich in basalt/red chert cemented by hemipelagic limestones, pelagic to fossiliferous-reefal imestones; Albian-Cenomanian to Paleocene-Middle Eocene age

NW-verging thrust faulting related to post-Eocene compressional phase

Flysch desposits: calcite shales, reddish fossiliferous marls, sandy-marls, conglomerates and sandstone turbidite intercalated with clastic limestones. Lower horizons are ophiolitic bodies containing fragments of pillow-lavas, diabase, and serpentinized peridotites; deformed-to-undeformed, folded; post-Early Eocene age

Figure 3. Stratigraphic column of the vicinity of (a) Tiryns and (b) Midea [after Hinojosa-Prieto and Hinzen, 2015 and Hinojosa-Prieto, 2016, respectively]. 


\section{Hector R. Hinojosa-Prieto}

Fallen blocks of the fortification walls are still scattered on the northern and eastern flanks (Figure 5) and were not considered as damaged structures by the former excavator Klaus Kilian. The west wall was to a great deal restored along its entire length in the 1960s, but segments of the eastern side still remain in the condition as described by Heinrich Schliemann in 1886 [Hinzen et al., 2013]. During the Mycenaean period, the citadel was surrounded by the so-called Lower Town (LT) [Zangger, 1993; Maran, 2010] (Figure 4). At Midea, the Cyclopean wall

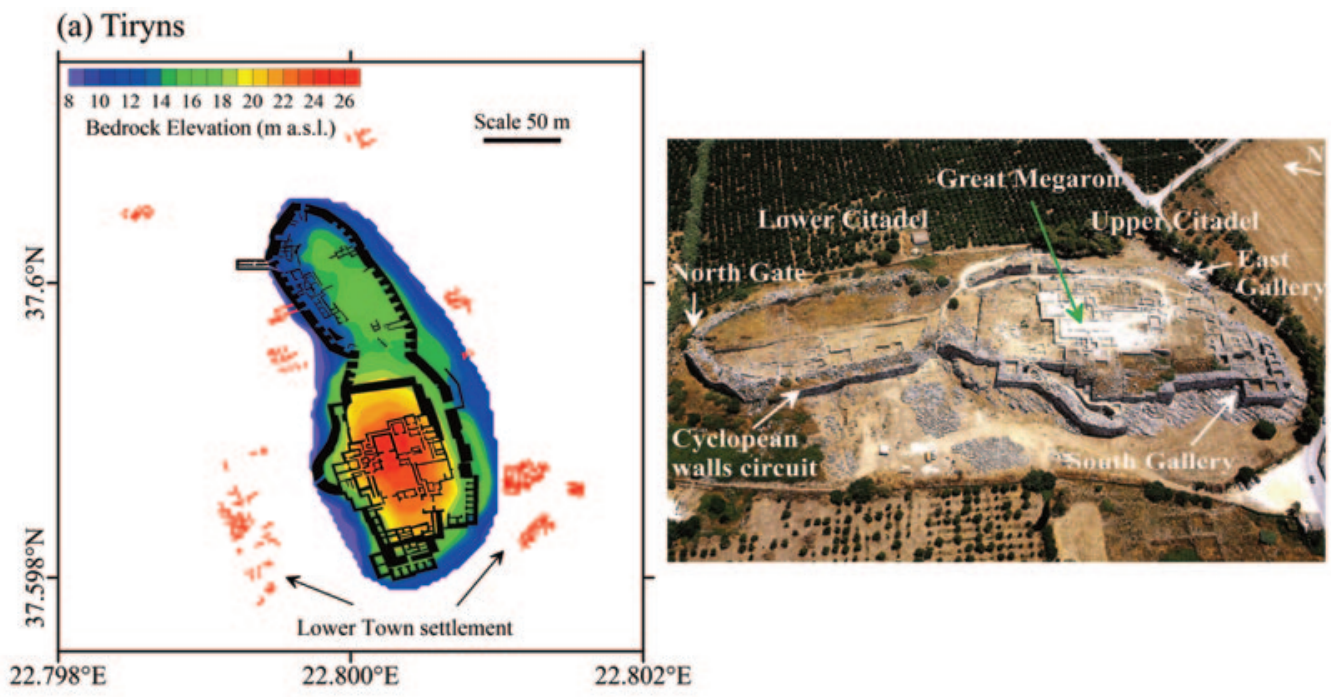

\section{(b) Midea}

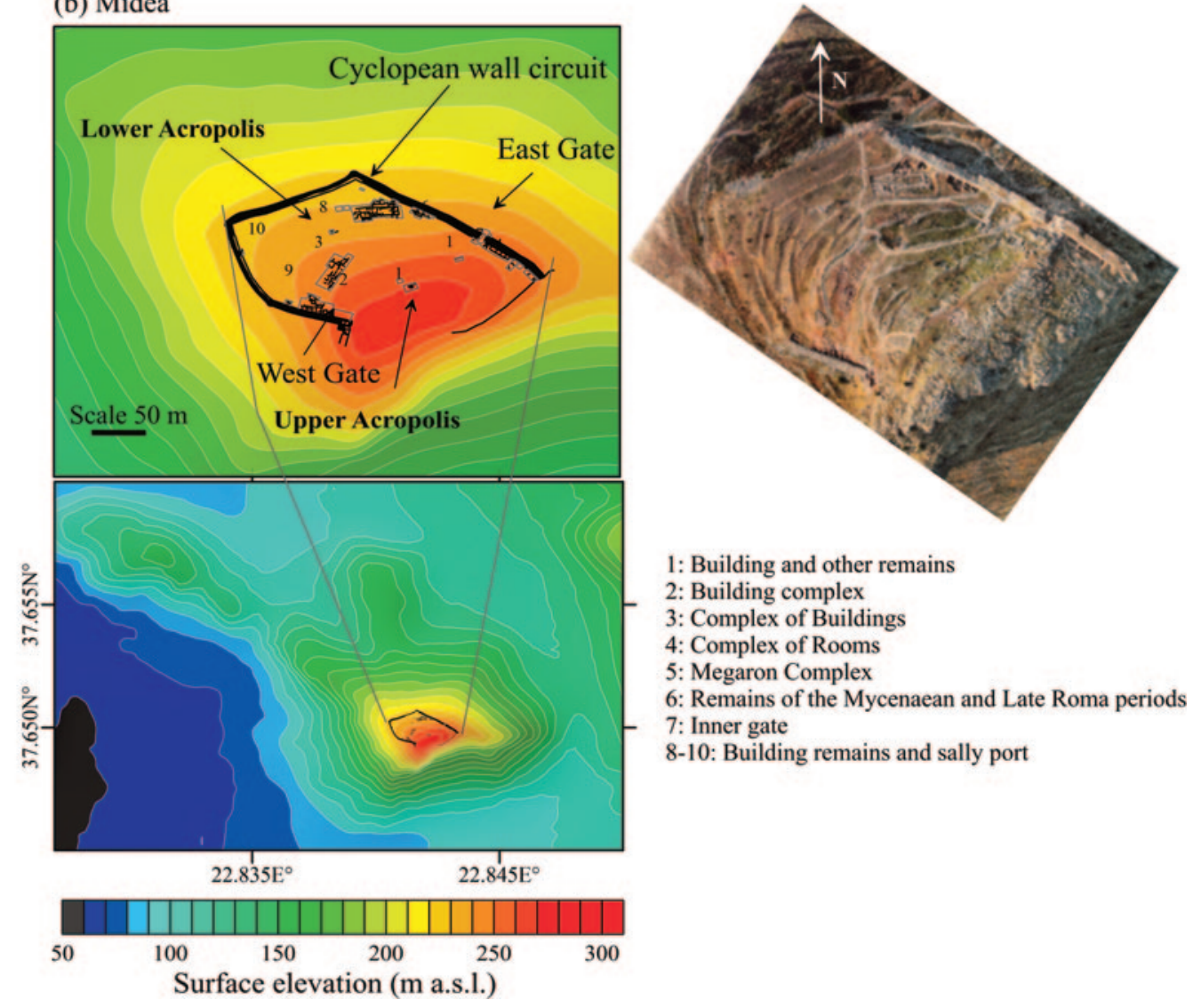

Figure 4. Archaeological plan of (a) Tiryns [Maran, 2004, 2010] and (b) Midea [Demakopoulou, 2012] superimposed on the bedrock elevation map of Tiryns and topographic map of Midea with aerial photograph of Tiryns [photograph by Daskalopoulou and Patrikianos in Papadimitriou, 2001] and Midea [photo by K. Xenikakis in Demakopoulou, 2012], respectively. 


\section{Earthquake site effects in Archaeoseismology}

circuit is $450 \mathrm{~m}$ long, 5 to $7 \mathrm{~m}$ thick, partially preserved up to a height of $7 \mathrm{~m}$, and encloses an area of $24,000 \mathrm{~m}^{2}$ [Walberg, 2001; Demakopoulou, 2012]. Blocks of the collapsed wall are scattered on the northern slope (Figure 5) and excavations continue unearthing further remnants of it. Hinzen et al. [2018] present three-dimensional laser scans of the Cyclopean walls of Tiryns and Midea and an analysis of individual damage descriptions and observations from the archaeological literature on which the earthquake hypothesis is based on.

(a) Tiryns

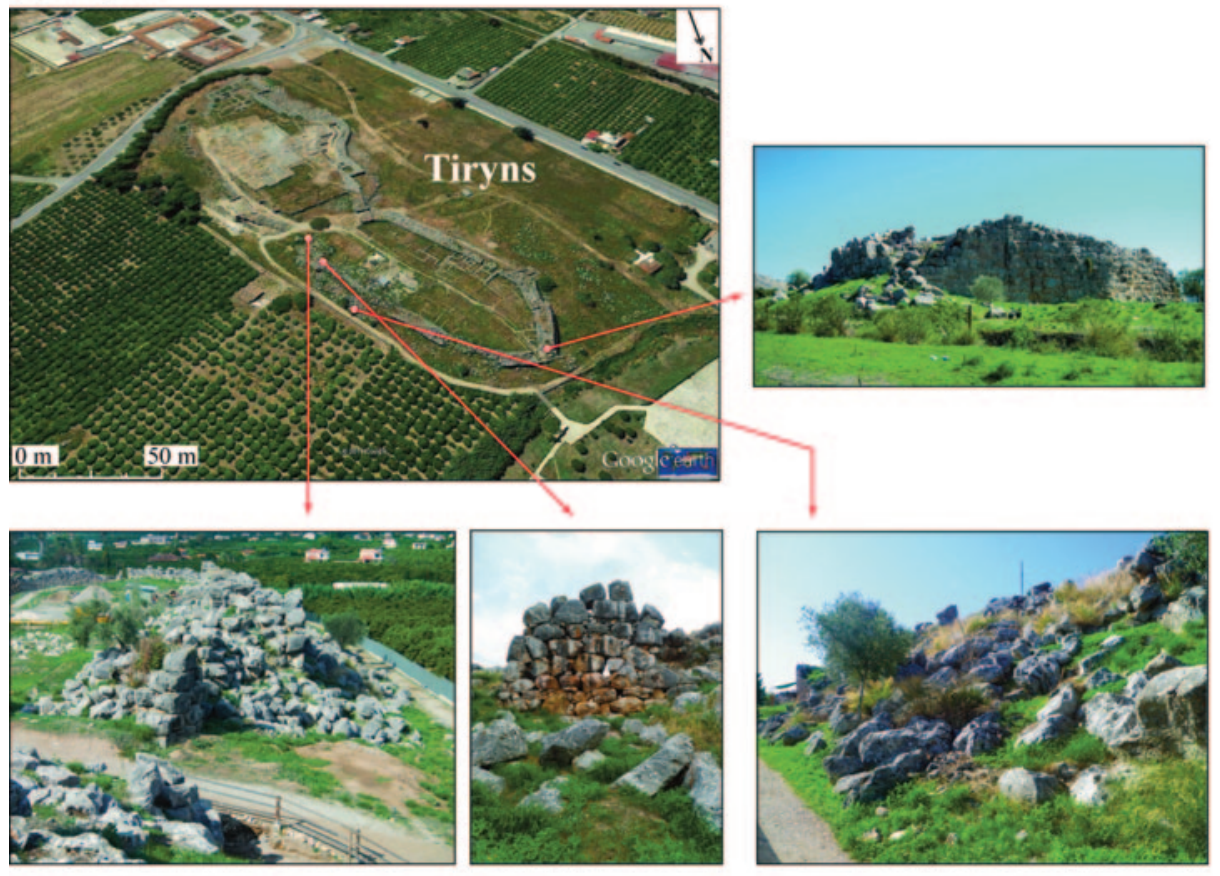

(b) Midea

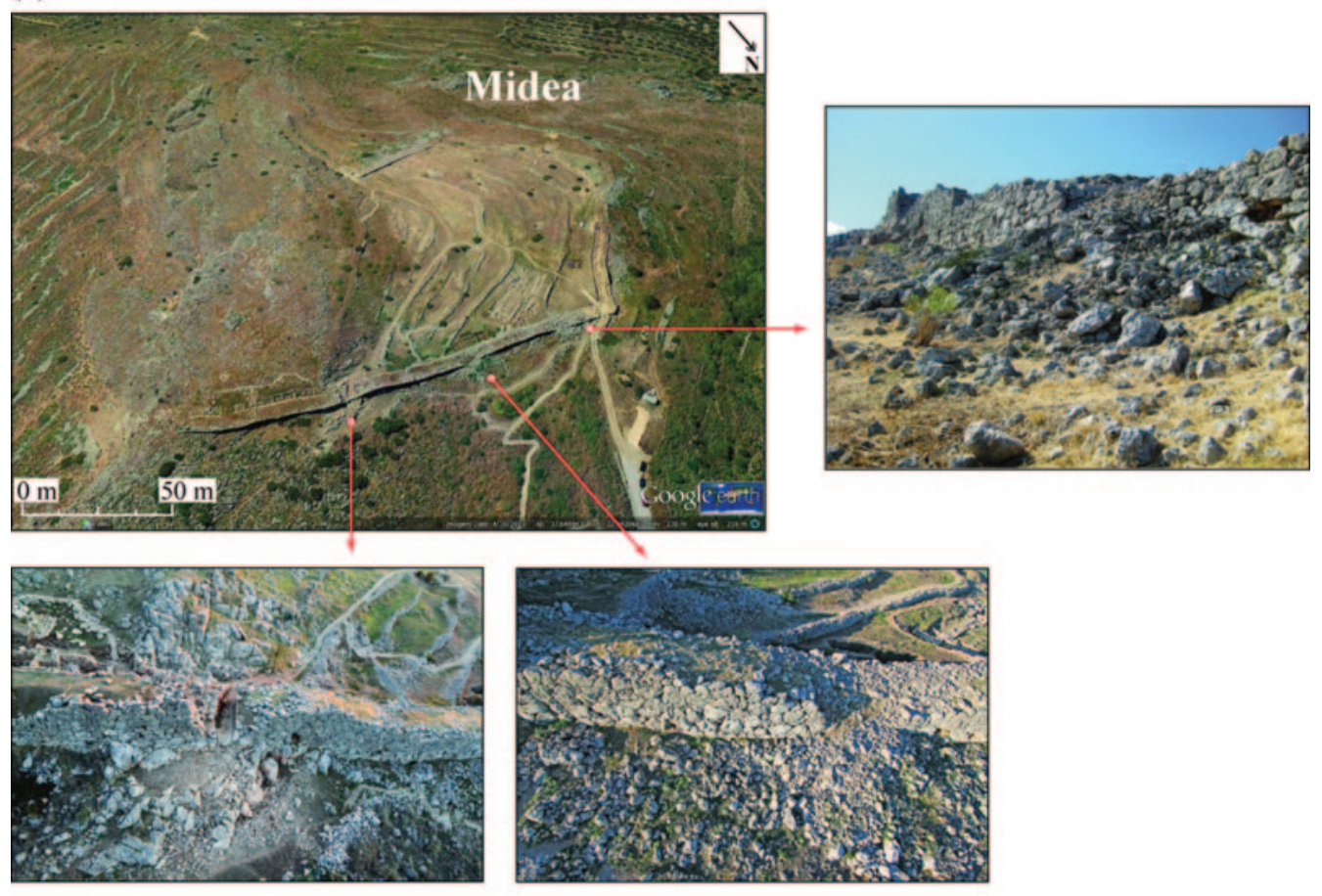

Figure 5. Satellite image of (a) Tiryns and (b) Midea showing the position of several collapsed blocks of the Cyclopean wall [taken from Hinojosa-Prieto, 2016; satellite image from Google Earth ${ }^{\oplus}$, inset photos of Tiryns by author inset photos of Midea by K.-G. Hinzen [upper-right] and K. Xenikakis (bottom ones)]. 


\section{An archaeoseismic view of the earthquake hypothesis}

A generation of academic researchers has been arguing that earthquakes during the LBA caused structural damage to Mycenaean citadels in and outside the $\mathrm{AB}$ (the citadels outside the $\mathrm{AB}$ and neither the Mycenae and Argos citadels located near Tiryns and Midea are the scope of this paper). Since its proposal, the earthquake hypothesis has left unexplained the size and strength of the probable causative LBA earthquake(s) and has disregarded the influence of local site effects that has on surface ground-motion and earthquake intensity. This stems on the fact that there had never been such interdisciplinary discourses and it was until recent times when quantitative archaeoseismic research began to shed light to this topic [i.e. AlTarazi and Korjenkov, 2007; Sintubin and Stewart, 2008; Korjenkov and Mazor, 2013; Hinzen et al., 2013; Helly and Rideaud, 2015; MinosMinopoulos et al., 2015; Hinzen et al., 2015, 2016; Hinojosa-Prieto, 2016; Hailemikael et al., 2017; Hinzen et al., 2018]. Yet, the hypothesis implicitly suggests that the postulated causative earthquake(s) brought synchronized co-seismic damage to Mycenaean structures (i.e., MMI (Modified Mercalli Intensity) $\geqslant$ VIII) at Tiryns and Midea without damaging numerous nearby vulnerable structures settled on the adjacent sedimentary plain [i.e. Papanastassiou et al., 1993; Gaki-Papanastassiou et al., 1996; Maroukian et al., 1996; Kilian, 1996; Åström and Demakopoulou, 1996]. From the seismological point of view, such scenario is rather improbable. If massive structures within the Tiryns and Midea citadels toppled (MMI $\geqslant$ VIII) due to local earthquake-induced ground shaking in the LBA, then fewer imposing structures built on the sedimentary plain would have also been damaged, toppled, or even destroyed; hence recording MMI $\geqslant$ VIII. In this scenario, physical evidence of a townwide devastation pattern would reveal in previous, ongoing, or future archaeological excavations outside the citadels. Indeed, excavation data from the LT still lacks evidence of co-seismic damage to Mycenaean structures. Moreover, the existence of an adjacent settlement next to Midea remains still unrevealed. Likewise, nearby concomitant important structures (i.e., buildings, tombs, and a massive dam) built on Holocene sediments (shallow to deep stiff soil sites) of the sedimentary plain also lack evidence of co-seismic damage [HinojosaPrieto, 2016]. Besides even if damage to structures is discovered during archaeological excavations, it has to be carefully documented and evaluated to be considered or classified as ancient co-seismic evidence. Moderate to great earthquakes with a short epicentral distance to a given site are not preconditions to cause structural damage. In some cases, is the influence of the local site effects that contributes the most to the size of damage area. Conversely, because of local site effects, moderate to great earthquakes with long epicentral distances can also be devastating.

It is important to emphasize that the term "earthquake hypothesis" used in this paper differs from the term "Mycenaean earthquake hypothesis" recently coined by Hinzen et al. [2018], which I am a co-author of. The former term is specifically linked to the presumed ca. 1190 BCE event proposed by Papanastassiou et al. [1993] and later supported by Gaki-Papanastassiou et al. [1996], Maroukian et al. [1996], Kilian [1996], and Åström and Demakopoulou [1996]. The later term holds a broader archaeological context, is also reevaluated in a quantitative multidisciplinary fashion, and refers to the idea that several Mycenaean sites in the $A B$ were destroyed by a sequence of large earthquakes between the late palatial (13th cent. BCE) and post-palatial (12001050 BCE) cultural periods.

\section{Modeling of earthquake source parameters and local site effects}

Written sources confirming the occurrence of earthquake ground-shaking in the AB during the age of the LBA do not exist [Hinojosa-Prieto, 2016; Hinzen et al., 2018]. This merit the estimation of the earthquake moment magnitude $\left(\mathrm{M}_{\mathrm{w}}\right)$, seismic moment $\left(\mathrm{M}_{\mathrm{o}}\right)$, and earthquake stress-drop $(\Delta \sigma)$ of the postulated ca. $1190 \mathrm{BCE}$ earthquake and its potential local site effects within the vicinity of Tiryns and Midea. A quasi-deterministic approach is adopted here. In general, the aforementioned earthquake source parameters are estimated in order to calculate synthetic seismograms that provide the input motions to a numerical model. Then, the role of local site effects is assessed in the form of seismic amplification factors, surface ground-motion, and macroseismic intensity at specific sites inside (rock sites) and outside (soil sites) the Tiryns and Midea citadels. Attention is paid to the effects of topographic amplifications [cf. Hinzen et al., 2016]. 


\subsection{Calculation of the $M_{w}, M_{0}$, and $\Delta \sigma$}

While both the value of the $\mathrm{M}_{\mathrm{w}}$ and $\mathrm{M}_{\mathrm{o}}$ are estimated using well-known empirical relations, the value of the $\Delta \sigma$ is rather taken from the earthquake stress-drop literature [Allmann and Shearer, 2009]. In this sense, the chosen $\Delta \sigma$ value has been computed by Allmann and Shearer [2009] using empirical data from instrumentally documented earthquakes worldwide that match the tectonic setting and focal mechanism of the alleged causative earthquake.

Some scholars consider the presumed ca. 1190 BCE event on the Mycenae fault to be a surface-rupturing earthquake [Papanastassiou et al., 1993; Gaki-Papanastassiou et al., 1996; Maroukian et al., 1996] or a morphogenic earthquake following Caputo [2005]. In earthquake geology, the use of geologic fault data is instrumental in the development of seismogenic source models [Di Toro et al., 2005; Haller and Basili, 2011; Mai et al., 2016]. Finitefault rupture models for global earthquakes are valuable for seismic-hazard, earthquake source processes, and seismotectonic research.

First, the Mycenaean normal fault has been suggested to represent the causative fault of the ca. 1190 BCE event (Figure 6) following available upfront geologic fault data of Papanastassiou et al. [1993] and geomorphologic field observations of Gaki-Papanastassiou et al. [1996] and Maroukian et al. [1996]. Together these observations suggest it is a morphogenic fault with normal sense of motion, with a fault surface rupture length (SRL) of $5 \mathrm{~km}$ affecting the outcropping bedrock comprised of weathered and fractured karstic limestone and flysch. In Greece, such crustal normal faults are typical and can trigger $\mathrm{M}_{\mathrm{w}} \geq 5.5$ earthquakes [Pavlides and Caputo, 2004]. The conspicuous fault scarp reaches up to $\sim 3 \mathrm{~m}$ such as the older (upper) half is intensely karstified. The fault's southern tip disappears in a small drainage basin at a distance of 13 and $8 \mathrm{~km}$ away from Tiryns and Midea, respectively.

Second, the mapped geological fault length of Papanastassiou et al. [1993] is taken to represent the SRL of the Mycenae fault. Then the SRL is used to estimate the $\mathrm{M}_{\mathrm{W}}$ of the assumed ca. 1190 BCE earthquake using the empirical $\mathrm{M}_{\mathrm{W}}$ relationship of Pavlides and Caputo [2004] specifically derived for shallow crustal Greek normal faults (equation 1):

$$
M_{w}=5.48+0.90 \cdot \log (\mathrm{SRL})
$$

resulting in a $\mathrm{M}_{\mathrm{W}}=6.1$. Following the $\mathrm{M}_{\mathrm{o}}$ and $\mathrm{M}_{\mathrm{w}}$ empirical relationship of Hanks and Kanamori [1979] (equation 2), the computed $M_{0}$ results in $1.83 \times 10^{25}$ dyne-cm,

$$
M_{o}=10^{\left(3 / 2 M_{w}+16.1\right)}
$$

Expressed in Newton-meter, $\mathrm{M}_{\mathrm{o}}=1.83 \times 10^{18} \mathrm{~N} \cdot \mathrm{m}$.

Third, the down-dip rupture width (DRW) of the Mycenaean normal fault is calculated using the well-known global empirical relationship of Wells and Coppersmith [1994] (equation 3):

$$
D R W=10^{\left(-1.01+\left(0.32 M_{W}\right)\right)}
$$

resulting in a DRW $=8.75 \mathrm{~km}$. In the Mediterranean region, fault dimensions with DRW $\geqslant$ SRL are common for light to strong crustal earthquakes [Konstantinou, 2014].

Fourth, to estimate the probable ancient surface ground-motions induced by the postulated ca. 1190 BCE earthquake, synthetic horizontal (NS and EW) acceleration seismograms were computed for outcropping bedrock sites using the Green's function method by Wang [1999]. The Green's function method has successfully been applied in quantitative archaeoseismology [Caputo et al., 2010; Hinzen et al., 2011; Hinojosa-Prieto, 2016; Hinzen et al., 2018], in earthquake engineering [Somerville and Moriwaki, 2003] and earthquake seismology [Denolle et al., 2014]. The calculation of the Green's functions requires a multi-layered half-space earth model to compute the synthetic seismograms. The earth model was taken from Hinojosa-Prieto [2016], which comprises density, seismic attenuation, 


\section{Hector R. Hinojosa-Prieto}

and three-dimensional velocity structure data from the Aegean region of Greece. A unilateral southward earthquake rupture (towards the citadels) was assumed. The earthquake source is represented by dislocation planes and a summary of the input modeling parameters is shown in Table 2 . The hypocenter is assumed to be at the northernmost bottom corner of the fault plane resulting in a $6 \mathrm{~km}$ focal depth. From the seismological point of view, this assumed focal depth is in agreement with the average focal depth $(7 \mathrm{~km})$ where seismic energy is released by shallow crustal Greek earthquakes [Maggi et al., 2000; Margaris et al., 2002; Skarlatoudis et al., 2003; Konstantinou, 2014]. Figure 7 shows the resulting synthetic horizontal ( $\mathrm{X}$ and $\mathrm{Y}$ ) acceleration seismograms of the reference-stations located on a virtual rock site at Tiryns and Midea, which served as input signals to dynamically load one-dimensional (1D) geologic models.

Fifth, the $\Delta \sigma$ is an input source parameter in most ground-motion simulation methods that controls high frequencies and its determination is a major concern for the prediction of high-frequency ground-motions (e.g., peak ground-motions and peak ground velocities) [Wang, 1999; Caputo and Caputo, 2016; Courboulex et al., 2016]. The estimation of the $\Delta \sigma$ is achieved by the examination of digital acceleration records. While this is a routine for instrumental earthquakes, it is virtually impossible to estimate the $\Delta \sigma$ for ancient earthquakes from which there is no available seismogram to examine. For the calculation of synthetic seismograms of the estimated $\mathrm{M}_{\mathrm{w}}=6.1 \mathrm{event}$,
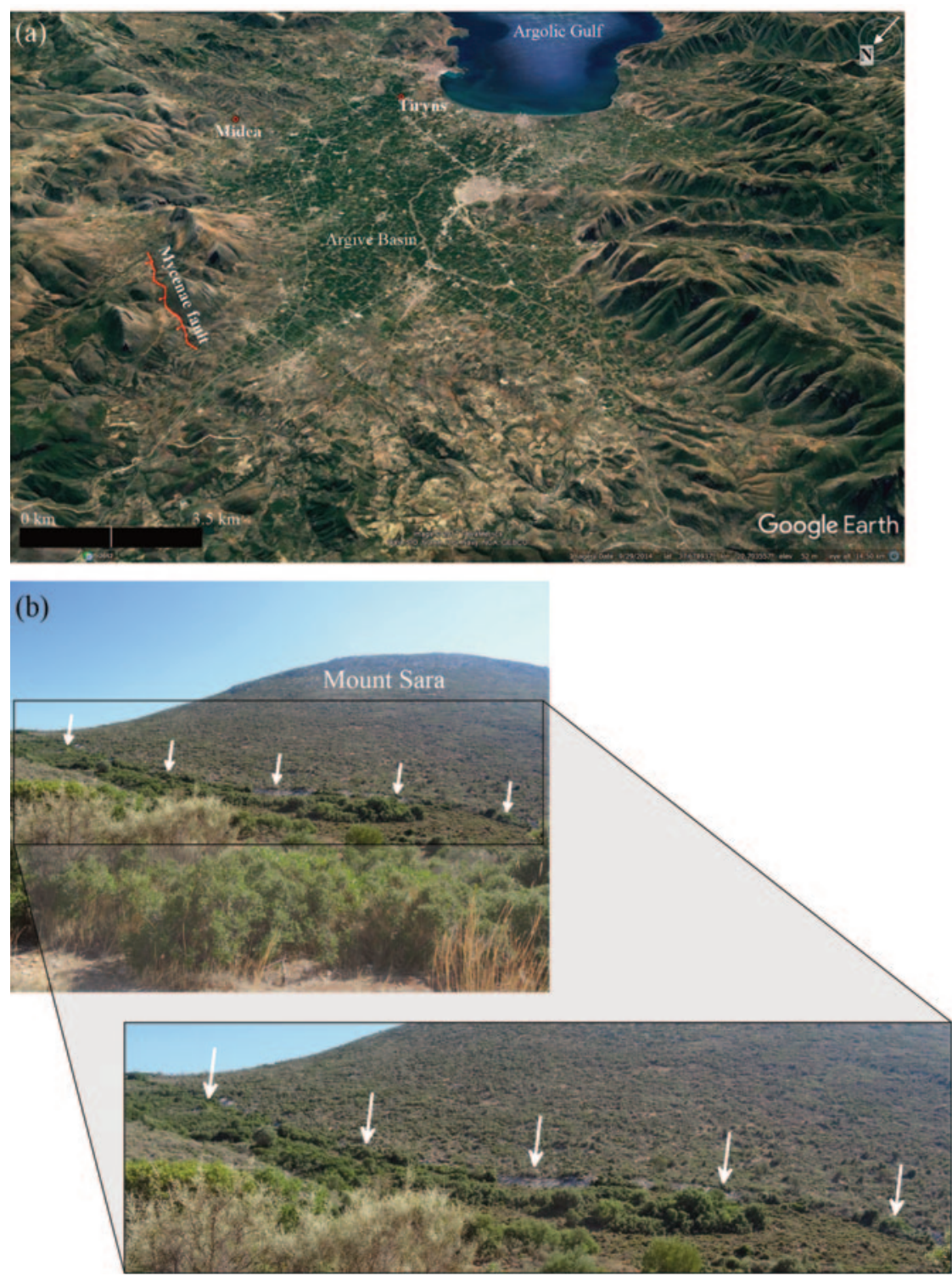

Figure 6. Satellite image of the (a) Argive Basin, Greece showing the Mycenae fault scarp (image from Google Earth ${ }^{\circledR}$ ) and field photographs of (b) the Mycenae fault scarp (photo by S. Mechernich). 

$M_{W}$
6.1
estimated in this study
(see section 4.1 for criteria)

\begin{tabular}{|c|c|c|}
\hline$M_{O}$ & $1.83 \times 10^{18} \mathrm{~N} \cdot \mathrm{m}$ & estimated in this study (section 4.1 ) \\
\hline $\begin{array}{l}\text { Reference depth (to upper } \\
\text { edge of fault) }\end{array}$ & $0 \mathrm{~m}$ & $\begin{array}{c}\text { Papanastassiou et al. [1993] and } \\
\text { Gaki-Papanastassiou et al. [1996] (morphogenic } \\
\text { earthquake) }\end{array}$ \\
\hline Surface rupture length (SRL) & $5000 \mathrm{~m}$ & $\begin{array}{l}\text { Papanastassiou et al. (1993) (based on geologic } \\
\text { field data) }\end{array}$ \\
\hline Fault strike, dip, and rake & $245^{\circ} \pm 10^{\circ}, 42^{\circ} \pm 10^{\circ},-90^{\circ} \pm 0^{\circ}$ & $\begin{array}{l}\text { Papanastassiou et al. [1993] } \\
\text { (based on geologic field data) }\end{array}$ \\
\hline Earthquake stress-drop $(\Delta \sigma)$ & $6 \mathrm{MPa}$ & $\begin{array}{l}\text { Allmann and Shearer [2009] } \\
\text { (median value for intraplate earthquakes) }\end{array}$ \\
\hline Hypocenter depth & $6000 \mathrm{~m}$ & $\begin{array}{l}\text { Maggi et al. [2000], Margaris et al. [2002] and } \\
\text { Skarlatoudis et al. [2003] (assumed based on } \\
\text { average seismogenic depth of shallow } \\
\text { crustal Greek earthquakes) }\end{array}$ \\
\hline Rupture velocity & $2680(\mathrm{~m} / \mathrm{s})$ & $\begin{array}{l}\text { adopted for this study (assuming unilateral } \\
\text { rupture towards citadels) }\end{array}$ \\
\hline
\end{tabular}

Table 2. Input parameters of the archaeologically proposed ca. 1190 BCE earthquake used to calculate synthetic horizontal acceleration seismograms using the Green's function approach of Wang [1999].

I carefully implemented the median $\Delta \sigma$ value of $6 \mathrm{MPa}$ for intraplate earthquakes following the global earthquake database of Allmann and Shearer [2009]. At first glance, this choice of value might seem subjective because earthquake $\Delta \sigma$ worldwide show a broad variability of magnitude (see Caputo and Caputo, 2016); however, it is a statistically valid and meaningful choice because it represents the median stress-drop value for specific type of tectonic setting. Several lines of seismological and tectonic evidence strongly support this adopted $\Delta \sigma$ value:

a) Intraplate earthquakes occur along faults in the normally stable interior of plates or crustal blocks, but not near plate boundaries. Under this premise, together the south Aegean and the Peloponnese behave as a single rigid block deformed by active crustal faults and active plate boundaries [Goldsworthy et al., 2002] where the main seismic hazard can come from local earthquakes with $M_{\mathrm{w}} \leqslant 6.5$ [Konstantinou, 2014]. This line of thought suggests that potential shallow crustal earthquakes along normal faults within the $A B$ half-graben are of intraplate nature, such as the Mycenaean normal fault. In other words, crustal normal faults in the $\mathrm{AB}$ are not related to interplate seismicity.

b) Conversely, across an area of interplate seismicity, small crustal earthquakes with local magnitudes $\left(\mathrm{M}_{\mathrm{L}}\right)$ of 1.5-3.1 and 0-4.88 can yield a mean $\Delta \sigma$ of $4 \mathrm{MPa}$ for normal fault earthquakes [Shearer et al., 2006; Goebel et al., 2015].

c) Shearer et al. [2006] report an increase of median $\Delta \sigma$ from $\sim 0.6 \mathrm{MPa}$ at the surface to $\sim 2.2 \mathrm{MPa}$ at $8 \mathrm{~km}$ where it levels off and remains nearly constant in the middle crust down to $\sim 20 \mathrm{~km}$. This is remarkably consistent with the recent empirical relationship between earthquake stress-drop and depth of strong motion generation areas for all types of faults following Satoh and Okazaki [2016] that predicts that $\Delta \sigma$ increases by $\sim 1 \mathrm{MPa}$ every $1 \mathrm{~km}$ in depth. The equation is based on broadband source models for crustal earthquakes estimated by the empirical Green's function method. This is in excellent agreement with the estimated $6 \mathrm{~km}$ hypocentral depth and the carefully selected $6 \mathrm{MPa}$ intraplate $\Delta \sigma$ value. 
(a)
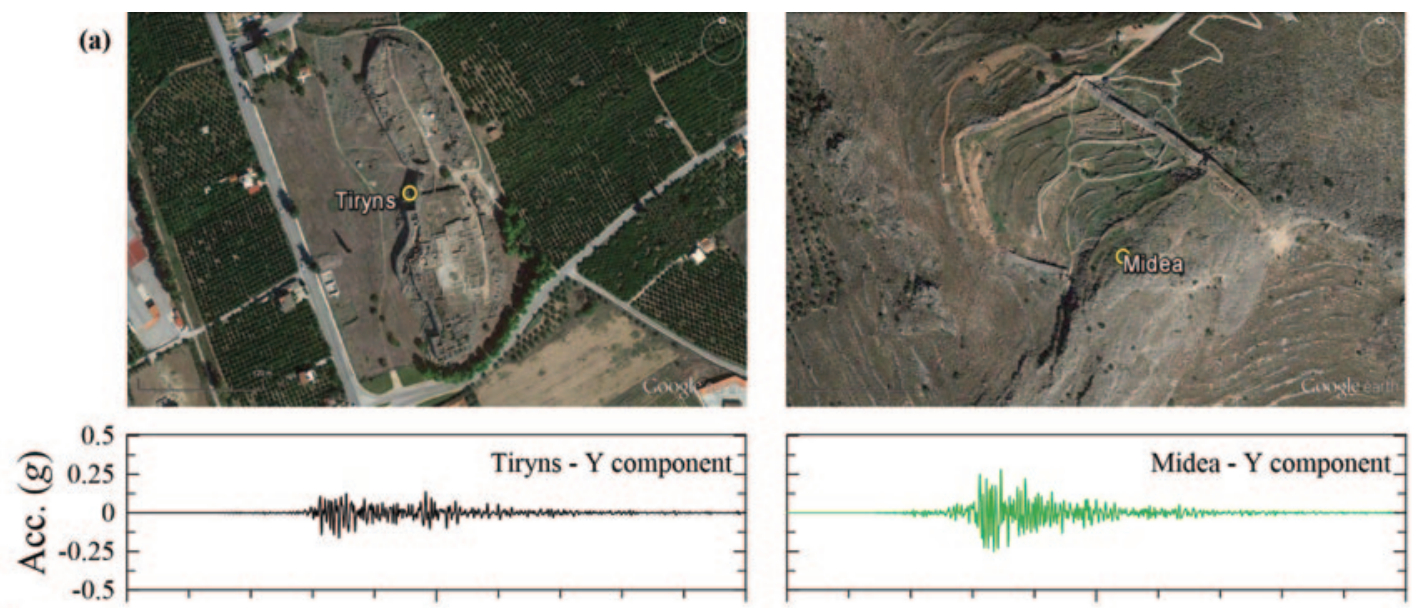

(b)
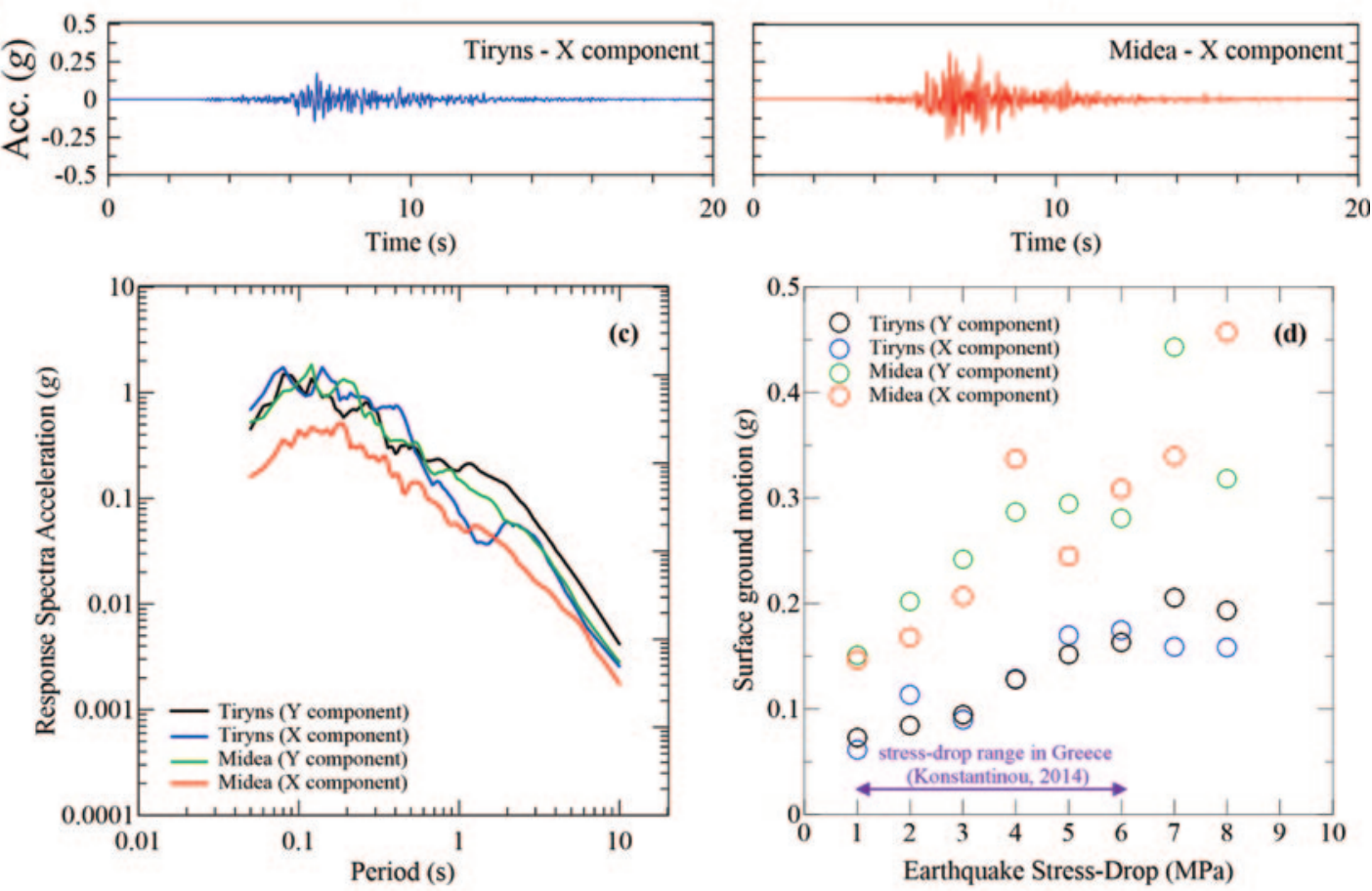

Figure 7. Location of (a) the virtual refence-station used to compute the synthetic input motion for Tiryns' and Midea's outcropping bedrock for the numerical analyses. (b) Synthetic horizontal input motions of the estimated $\mathrm{M}_{\mathrm{w}} 6.1$ earthquake calculated for each reference-station and (c) corresponding acceleration response spectra plot for each input motion in (b). (d) Variation of the maximum surface ground-motions as a function of earthquake stress-drop for each input motion (see Table 2). A stress-drop value of 6 and $3 \mathrm{MPa}$ is used by this study and by Hinzen et al. [2018] respectively.

d) The average depth where seismic energy is released by shallow crustal Greek earthquakes is $\sim 7 \mathrm{~km}$ [Maggi et al., 2000; Margaris et al., 2002; Skarlatoudis et al., 2003; Konstantinou, 2014]. Again, the modeled hypocentral depth of $6 \mathrm{~km}$ of the ca. 1190 BCE event is consistent with such well-accepted seismological observations and the modeled fault geometry estimated with also well-accepted empirical relations (i.e. equations 1 and 2).

e) Crustal earthquakes with $\mathrm{M}_{\mathrm{w}}=4.4-7.5$ in the Mediterranean region exhibit stress-drops within a narrow band of 1-6 MPa and earthquakes with $\mathrm{M}_{\mathrm{o}}>1 \times 10^{18} \mathrm{~N} \cdot \mathrm{m}$ gradually approach $\Delta \sigma=6 \mathrm{MPa}$ [Konstantinou, 2014]. This is consistent with the $\Delta \sigma$ range of 0.01 to $6 \mathrm{MPa}$ for shallow ( $\leq 35 \mathrm{~km}$ ) crustal earthquakes $\left(\mathrm{M}_{\mathrm{w}}>5.8\right)$ extracted from a global database of source time functions and focal mechanisms recently compiled by Courboulex et al. [2016]. 
f) In order to investigate the influence of the earthquake stress-drop on the horizontal seismic input signals for the reference-station at Tiryns and Midea, several synthetic input signals were computed as a function of stressdrop varying from 1 to $8 \mathrm{MPa}$, which covers the aforementioned narrow range for events in the Mediterranean region including Greece [cf. Konstantinou, 2014], while other input source parameters were kept fixed (see Table 2). Figure $7 \mathrm{~d}$ shows the results compared against the selected stress-drop of $6 \mathrm{MPa}$ (this study) and $3 \mathrm{MPa}$ used by Hinzen et al. [2018]. As shown in Figure 7d, using a stress-drop value of 5, 7 and 8 MPa produces ground motions comparable to the ground motions modeled with a stress-drop value of $6 \mathrm{MPa}$. Indeed, the $\Delta \sigma$ values between 5 to $8 \mathrm{MPa}$ yield a constant range of maximum surface ground-motions. Conversely, using stress-drop values between 1 to 4 MPa yields lesser ground motion levels [cf. Hinzen et al., 2018].

In short, both the computed mean $\Delta \sigma$ values of Goebel et al. [2015] ( 4 MPa) and Shearer et al. [2006] (4 \pm 0.7 $\mathrm{MPa}$ ) for crustal normal fault earthquakes are representative of interplate normal faulting earthquakes and are significantly lower than the median $\Delta \sigma$ value (6 MPa) of Allmann and Shearer [2009] which corresponds to intraplate earthquakes at a global scale. So, selecting the mean $\Delta \sigma$ value of either Goebel et al [2015] or Shearer et al. [2006] over the median $\Delta \sigma$ value of Allmann and Shearer [2009] would be an inaccurate choice because is not representative of crustal intraplate extensional seismicity. In addition, the modeling of different stress-drop values suggest that the forward modeling of the local site effects leads to a consistent interpretation. Therefore, the carefully chosen median value of $\Delta \sigma=6 \mathrm{MPa}$ is well justified because is consistent with seismological parameters including the seismogenic depth of Greek crustal intraplate earthquakes, with the focal mechanism, $M_{w}, M_{o}$, and the fault dimensions (see Table 2). In other words, it represents the $\Delta \sigma$ value of crustal extensional intraplate earthquakes of the region. Last but not least, selecting a $\Delta \sigma$ value either lower or higher than the median $\Delta \sigma$ value would introduce a statistical bias.

\subsection{Calculation of the local site effects}

Local site effects, propagation wave path from source to site, and source have a profound influence on seismic ground-motion and macroseismic intensity. The quantitative evaluation of local site effects is crucial for assessing the seismic hazard of a region. Local site effects are understood as significant differences in recorded surface groundmotions and/or observed structural damage within an area affected by earthquake ground-shaking due to site-specific geologic and topographic conditions [Aki, 1993; Boore, 2004; Panzera et al., 2013]. The effects of surface topography are mainly attributed to ridges, canyons, cliffs, and slopes. Local site effects are controlled by variations in the elastic properties of the subsurface materials and can influence the amplitude, frequency content and duration of ground shaking, and can increase co-seismic damage and casualties [Şafak, 2001]. The evaluation of local site effects is done globally for recent and future earthquakes on a routine basis [Boore, 2004], but is rare for ancient earthquakes. A few examples of local site effects studies exist in the archaeoseismological literature [see Caputo et al., 2010; Hinojosa-Prieto, 2016; Hinzen et al., 2016, 2018].

Accrued soils younger than ca. 1190 BCE (i.e., the archaeological horizon of interest) were removed from the archaeological stratigraphy in order to reconstruct the site conditions at the end of the palatial period and minimize an over- or-underestimation of the local site effects. To capture the essential features controlling the probable ancient local site effects, multiple 1D site-specific stratigraphic models were developed (Figures 8 and 9) under the geotechnical site classification of Rodríguez-Marek et al. [2001]. This led to a total of 28 and 30 modeling sites for Tiryns and Midea, respectively, and a clear surface condition pattern throughout the region. Weathered hard rock sites (class C-1) represent the ground surface conditions inside the Tiryns and Midea citadels. Shallow stiff soil sites of class C-2 characterize the conditions outside the citadels. Intermediate depth stiff soil sites of class C-3 and lesser deep stiff Pleistocene soil sites of class D-2 occur further away from the citadels.

A terrain slope analysis of the Tiryns and Midea hills and its vicinities (foothills) was performed in order to consider topographic amplification effects, following the criteria by the Eurocode 8 (EC8) (EN-1998-5, 2004). The terrain slope angle was computed using the grid-calculus tool included in a commercial software (Surfer ${ }^{\oplus}$ version 10.7.972 by Golden Software, Inc.) based on the manual digitalization of $1.0 \mathrm{~m}$ contour spacing topographic charts made by the Hellenic Military Geographical Service (HMGS, 1951). The terrain slope analysis of the Tiryns and Midea hills and its vicinities indicates that the slope angle varies from 0 to $44.61^{\circ}$ and from 0 to $72.73^{\circ}$, respectively (Figure 10). 


\section{Hector R. Hinojosa-Prieto}
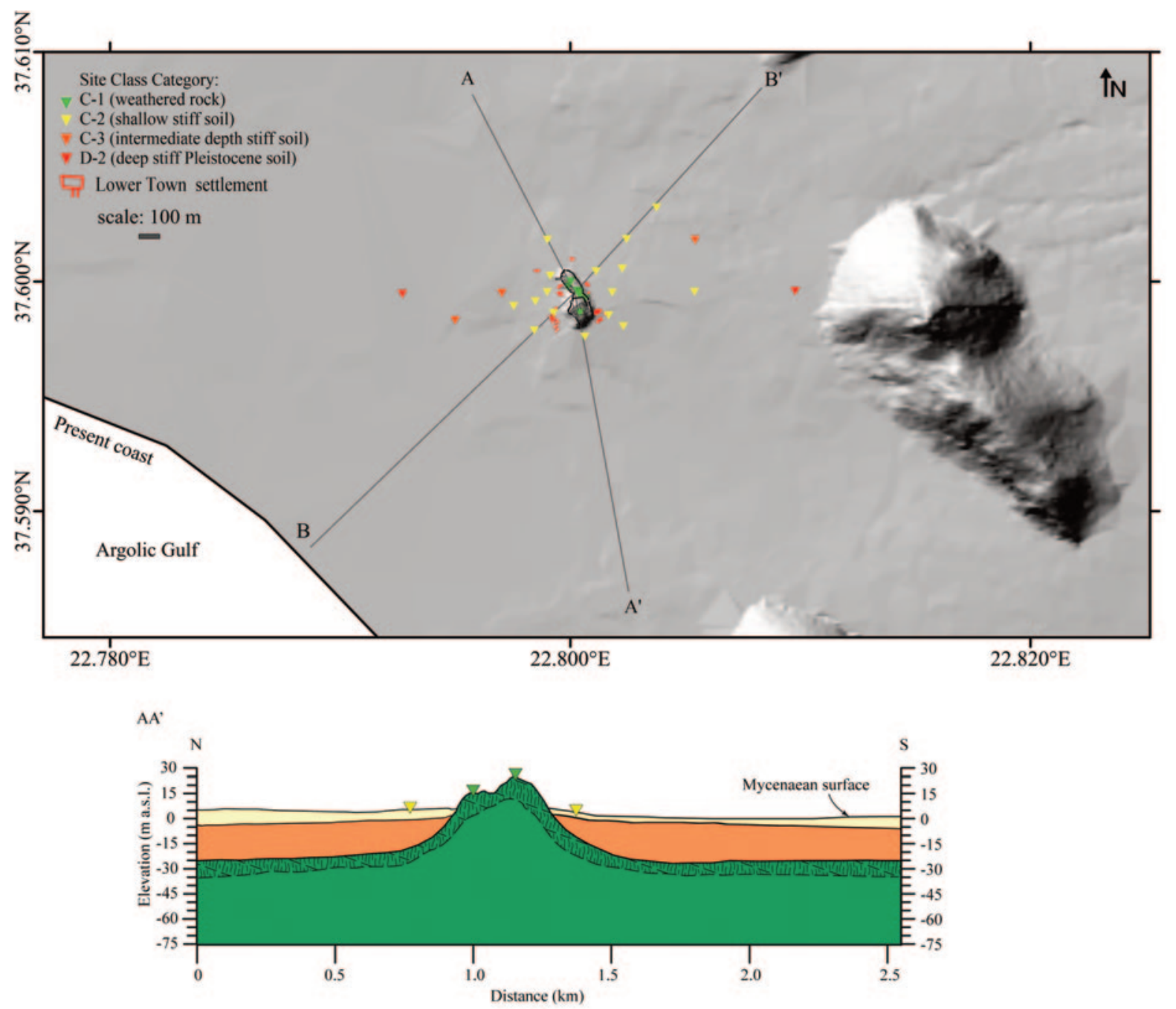

BB'

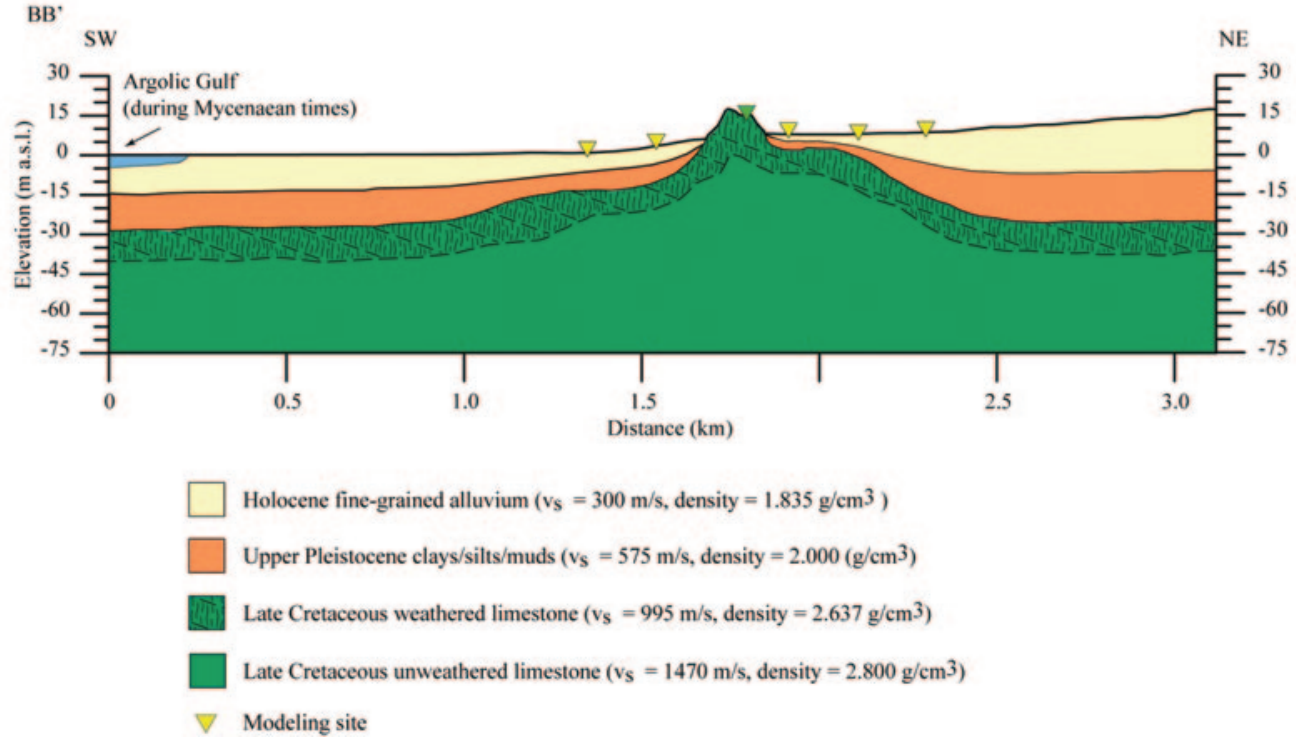

Figure 8. Distribution of modeling sites and site category and representative geologic cross-sections within the vicinity of Tiryns [after Hinojosa-Prieto, 2016]. 

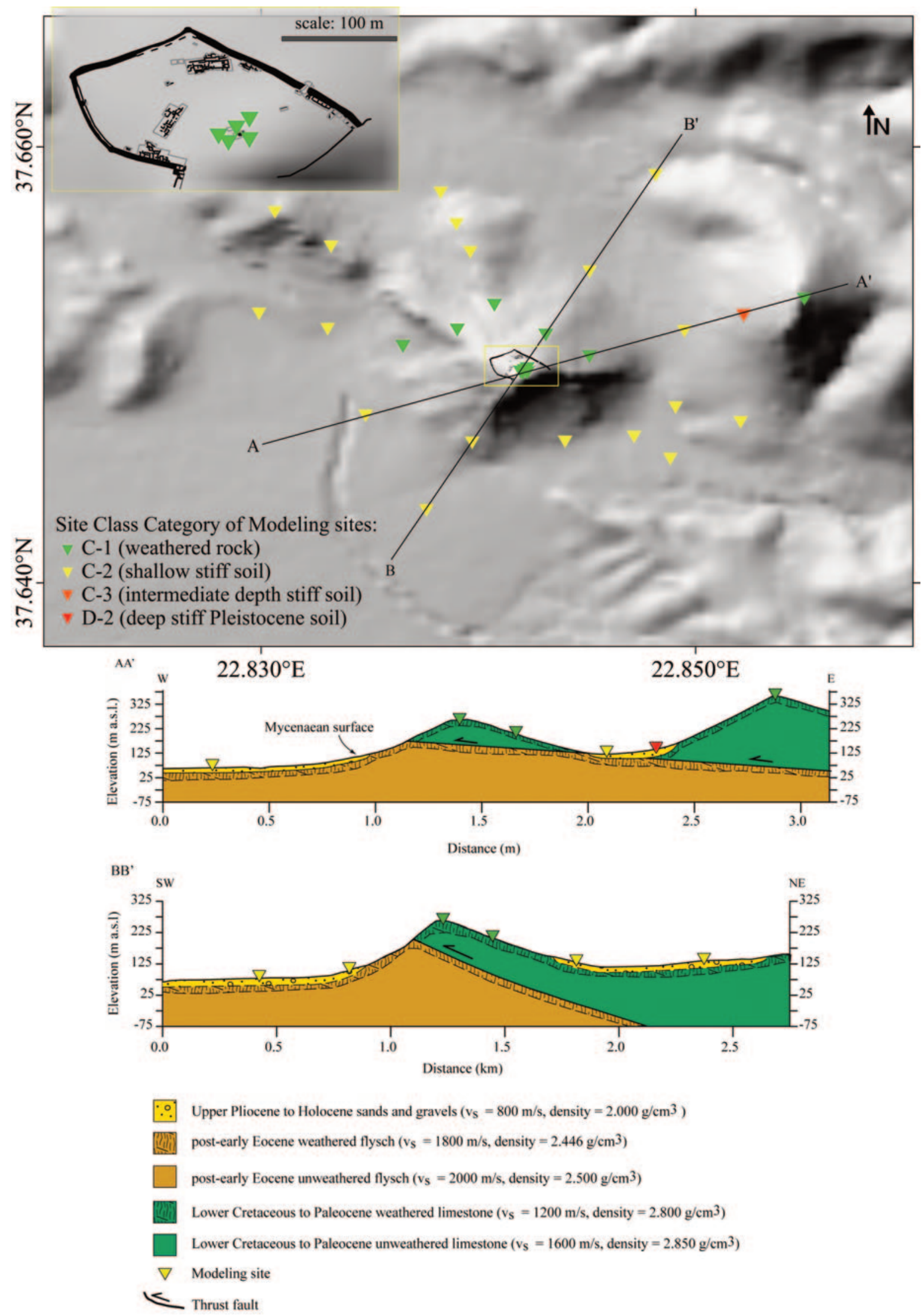

Figure 9. Distribution of modeling sites and site category and representative geologic cross-sections within the vicinity of Midea [after Hinojosa-Prieto, 2016]. 


\section{Hector R. Hinojosa-Prieto}

This means that the construction of fortification wall circuit of both citadels and their complex of rooms avoided slopes $\geq 30^{\circ}$, as shown in Figure 10. According to the EC8, topographic amplification factors, here referred simply as $\mathrm{S}_{\mathrm{T}}$, might or might not be quantified or considered for a given site; however, this action is ruled by the topographic conditions of the site under investigation. For instance, the $\mathrm{S}_{\mathrm{T}}$ are applied when the slopes of two-dimensional topographic features such as long ridges and cliffs of height greater than about $30 \mathrm{~m}$. This is the case of the Midea ridge, but not of Tiryns. Conversely, the $\mathrm{S}_{\mathrm{T}}$ may be neglected for topographic surfaces with average slope angles of less than $\sim 15^{\circ}$, like in the case of the Tiryns archaeological site. However, the estimation of $\mathrm{S}_{\mathrm{T}}$ is recommended in the case of strongly irregular local topography. For greater slope angles the following guidelines are applicable:

a) isolated cliffs and slopes: a value of $\mathrm{S}_{\mathrm{T}} \geq 1.2$ should be used for sites near the top edge;

b) ridges with crest width significantly less than the base width: a value of $\mathrm{S}_{\mathrm{T}} \geq 1.4$ should be used near the top of the slopes for average slope angles $>30^{\circ}$ and a value of $\mathrm{S}_{\mathrm{T}} \geq 1.2$ should be used for smaller slope angles;

c) presence of a loose surface layer: the smallest $\mathrm{S}_{\mathrm{T}}$ value given in (a) and (b) should be increased by at least $20 \%$;

d) spatial variation of amplification factor: the value of $\mathrm{S}_{\mathrm{T}}$ may be assumed to decrease as a linear function of the height above the base of the ridge or cliff, and to be unity at the base.
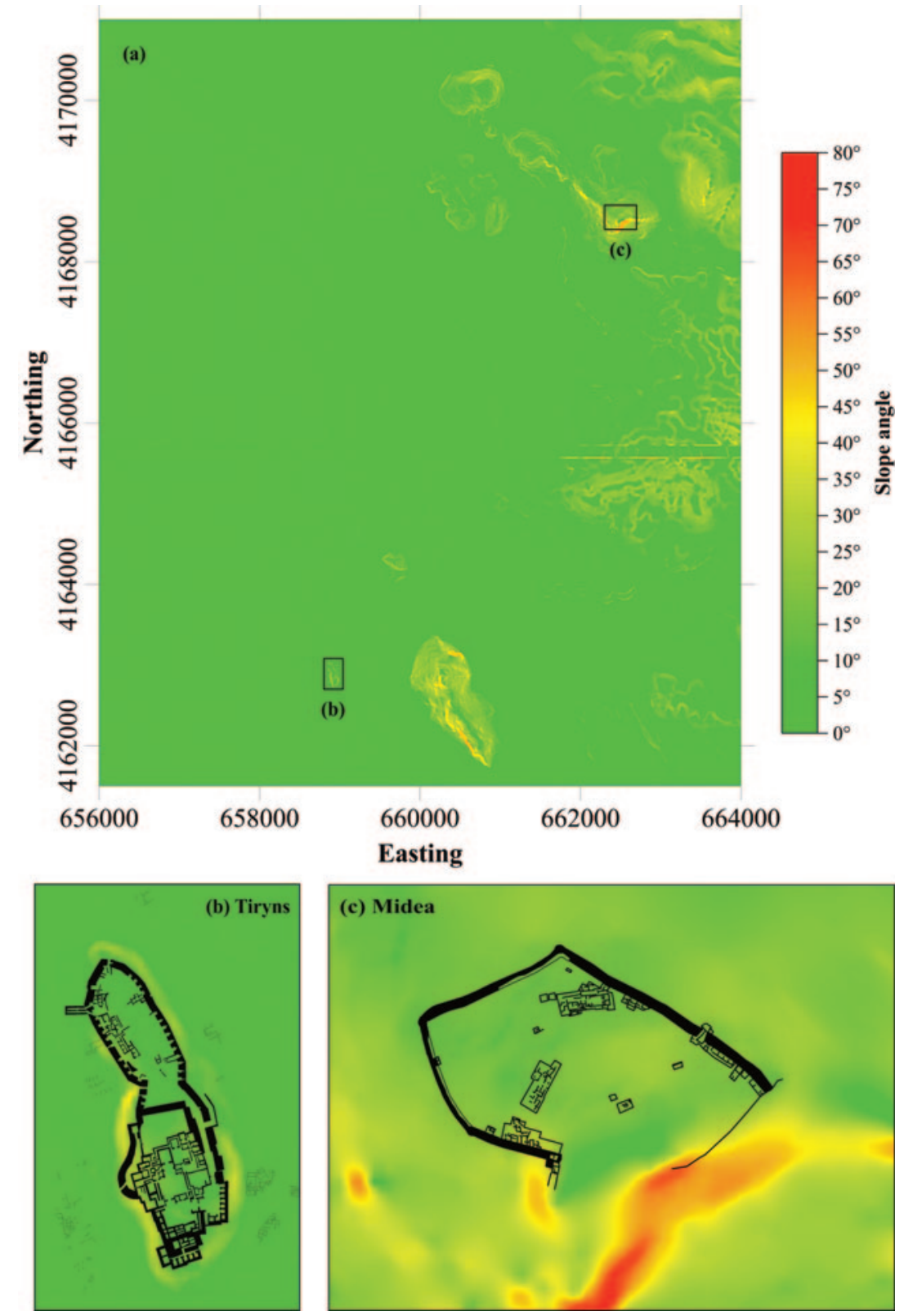

Figure 10. Terrain slope angle map of the (a) Tiryns-Midea tract and a zoom in to (b) Tiryns and (c) Midea archaeological sites. 
Following the aforementioned $\mathrm{S}_{\mathrm{T}}$ criteria coupled with the terrain slope angle analysis, both the Tiryns and Midea citadels meet EC8 criteria $a$ ) and $b$ ). Hence, a $\mathrm{S}_{\mathrm{T}}$ value $\geq 1.2$ would have to be considered for the wall circuit of Tiryns and for most areas within the wall circuit of Midea; however, the West Gate of Midea reaches the $30^{\circ}-32^{\circ}$ slope angle range so its expected $\mathrm{S}_{\mathrm{T}}$ value is $\geq 1.4$. Such $\mathrm{S}_{\mathrm{T}}$ values are in general agreement with the empirical research by Hinzen et al. [2016], who on the basis of empirical seismological engineering data estimated topographic amplification factors (i.e., $\mathrm{S}_{\mathrm{T}}$ ) of 2 to 3 at frequencies between 1 and $3 \mathrm{~Hz}$ at the Midea citadel, site amplifications factors $<2$ at frequencies between $2-10 \mathrm{~Hz}$ in the Tiryns citadel and amplifications of 4 to 6 at the soil sites around Tiryns. Though, the amplifications observed at the Tiryns hill are linked to the strong weathering of the exposed limestone bedrock, as highlighted by seismic and geotechnical microzonation [Hinojosa-Prieto and Hinzen, 2015; Hinojosa-Prieto, 2016] and other recent findings by a multi-method approach [Hinzen et al., 2018].

The numerical modeling and quantitative assessment of local site effects was achieved with a 1D EquivalentLinear site-specific response analysis using a set of MATLAB routines called SUA developed by Robinson et al. [2006]. The Equivalent-Linear site-specific response analysis, made within a frequency band from 0.1 to $20 \mathrm{~Hz}$, calculates seismic amplification factors and related surface ground-motions of a $1 \mathrm{D}$ regolith column in response to dynamic loading. It enables investigating how uncertainties in the input data (lithology, shear-wave velocity $\left(\mathrm{v}_{\mathrm{s}}\right)$, layer thickness, and layer density) affect the response functions. The uncertainty is taken into account by creating random numerous $\mathrm{v}_{\mathrm{s}}$ models (e.g. 50 in this case) from a user-specified normal distribution (i.e., mean and standard deviation) of average $\mathrm{v}_{\mathrm{s}}$ and layer thickness. Figure 11 shows an example of $\mathrm{v}_{\mathrm{s}}$-depth models for representative rock sites and soil sites from Tiryns and Midea. The input signals (i.e., synthetic NS and EW acceleration seismograms) correspond to the virtual reference-station located at each citadel (Figure 7). To simulate the nonlinear earth-material behavior, each modeling site is represented by a site-specific $1 \mathrm{D}$ regolith model consisting of several geologically constrained material layers over an elastic half-space (i.e., unweathered bedrock). The layers have an assigned lithology, layer thickness, $\mathrm{v}_{\mathrm{s}}$, density, and both strain-dependent shear modulus and damping values taken from Hinojosa-Prieto [2016]. This 1D approach is robust, widely used in engineering seismology, and has been extensively verified [Hasash, 2014; Ferraro et al., 2018], but does not take topographic relief into account though. For comparison, surface ground-motions were estimated using the empirical ground-motion attenuation relations of Margaris et al. [2002] and Danciu and Tselentis [2007] and the empirical peak ground-motion predictive relation of Skarlatoudis et al. [2003]. These equations were derived for shallow crustal Greek earthquakes and already account for the influence of local site effects.
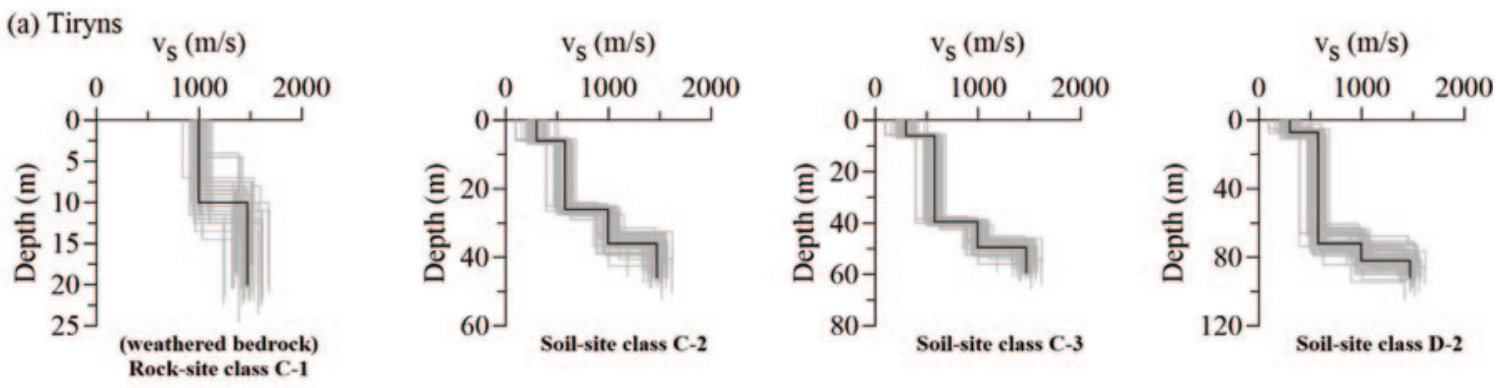

(b) Midea
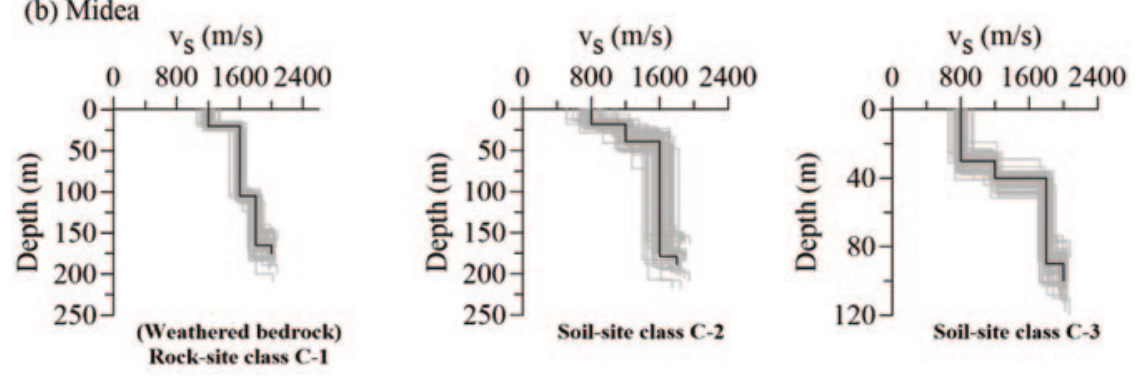

Figure 11. Example of implemented $1 \mathrm{D}$ average $\mathrm{v}_{\mathrm{s}}-$ depth models by site class category at (a) Tiryns and (b) Midea. Average $\mathrm{v}_{\mathrm{s}}$ base model (black line) and associated 50 randomly generated $\mathrm{v}_{\mathrm{s}}$ models (gray lines) shown in each plot. 


\section{Hector R. Hinojosa-Prieto}

The modified Mercalli intensity (MMI) scale is a descriptive macroseismic intensity scale that indicates the effects of earthquake ground shaking at a specific location, objects of nature, humans and man-made structures on a scale from I (not felt) to XII (total destruction). The macroseismic intensity depends on the properties of the source, the wave path from the source to the site, and the properties of the site where it is observed (e.g., the local site effects). Current seismological methods can estimate the contribution of the site effect based on source and path modeling of measured macroseismic intensities [Savvaidis et al., 1998]. Conversely, if the geologic conditions and archaeological stratigraphy of a given site are known upfront, this information can be used to estimate both surface ground-motions and macroseismic intensity with empirical relations. Here, the horizontal accelerations estimated in the previous step, which contain the influence of the geologic site conditions, are converted into MMI values using the empirical relationship of Ambraseys [1974] for Europe and Tselentis and Danciu [2008] for Greece represented by equations (4) and (5), respectively,

$$
\begin{gathered}
\text { MMI }=\frac{\log _{10} P G A_{H_{A}}+0.16}{0.36} \\
\text { MMI }=-0.946+3.536 \overline{\log _{10}\left(P G A_{H}\right)}
\end{gathered}
$$

where and correspond to the maximum horizontal peak ground acceleration (PGA) and the average of the horizontal PGA in units of $\mathrm{cm} / \mathrm{s}^{2}$, respectively.

\section{Numerical modeling results}

The geotechnical site microzonation reveals that the soil-bedrock interface deepens away from the citadels; however, the dynamic behavior of rock sites and soil sites is different at Tiryns and Midea. Class C-1 and C-2 sites from both citadels yield the lowest and highest seismic amplification factors (Figure 12), surface accelerations (Figure 13) and MMI values (Figure 14), respectively. Excavated Mycenaean structures discovered at C-1 sites of Tiryns and Midea are thought to show co-seismic damage. But excavations on C-2 soil sites at Midea are yet nonexistent; so, it is not possible to establish the existence of an adjacent contemporaneous settlement like in Tiryns. The few C-3 soil sites around both citadels and the absence of D-2 soil sites outside Midea preclude further intersite comparison; and the existence of buried Mycenaean structures at such sites remains unknown.

\subsection{Calculated seismic amplification factors}

Small seismic deamplifications $(\leq 1)$ have been observed at weathered and fractured bedrock sites [Steidl et al., 1996; Rodríguez-Marek et al., 2001; Robinson et al., 2006]. Figure 12 shows the seismic amplification factors estimated for both horizontal acceleration components (NS and EW) for the vicinity of Tiryns and Midea. Class C1 rock sites at both citadels yield a tight cluster of low seismic amplification factors $(1.5$ to $<2)$ for both horizontal acceleration components at 0.20 and $2 \mathrm{~Hz}$ and at 0.20 and 1-3 Hz for Tiryns and Midea, respectively. Class C-2 soil sites yield the widest range of seismic amplification factors, between 2 to 4.5 for Tiryns and 2 to 3 for Midea for both horizontal acceleration components within a frequency band of 3-14 Hz and $0.20-11 \mathrm{~Hz}$, respectively. Class C-3 soil sites at Tiryns yield amplification factors between 3 to 4 at a frequency band of 2-4 Hz for both acceleration components. At Midea, the one class C-3 soil site yields an amplification factor of 3 for both acceleration components at a frequency of $3 \mathrm{~Hz}$. The two class D-2 soil sites of Tiryns yield amplification factor of 3 at a frequency of $2 \mathrm{~Hz}$ for both horizontal acceleration components. For the soil sites, the varying seismic response is explained by the changing subsurface geologic conditions: lithology, textural heterogeneity, layer thickness, and material shear strength. In general, the cohesive soils around Tiryns yield the highest seismic amplification, compared to the stiffer granular soils around Midea. 
(a) Tiryns

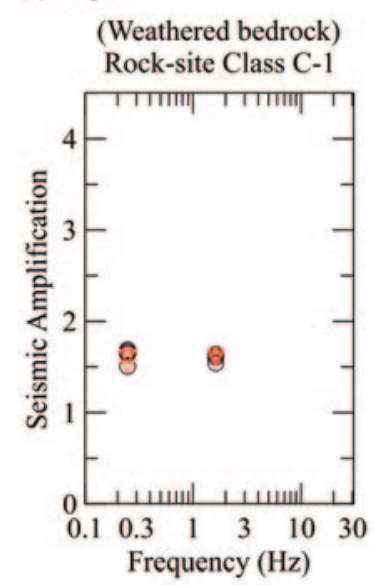

(b) Midea

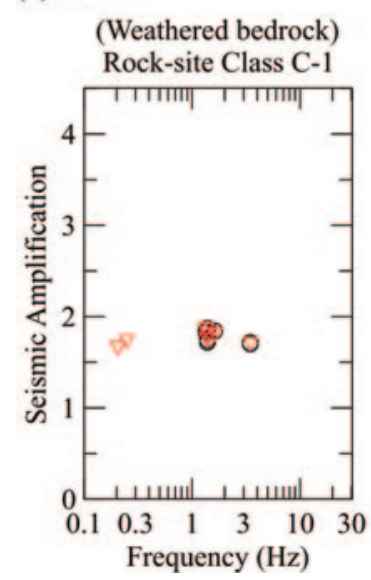

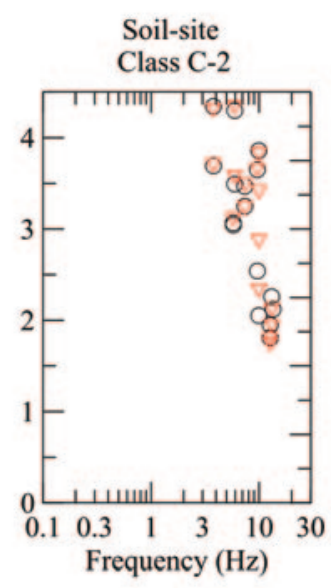
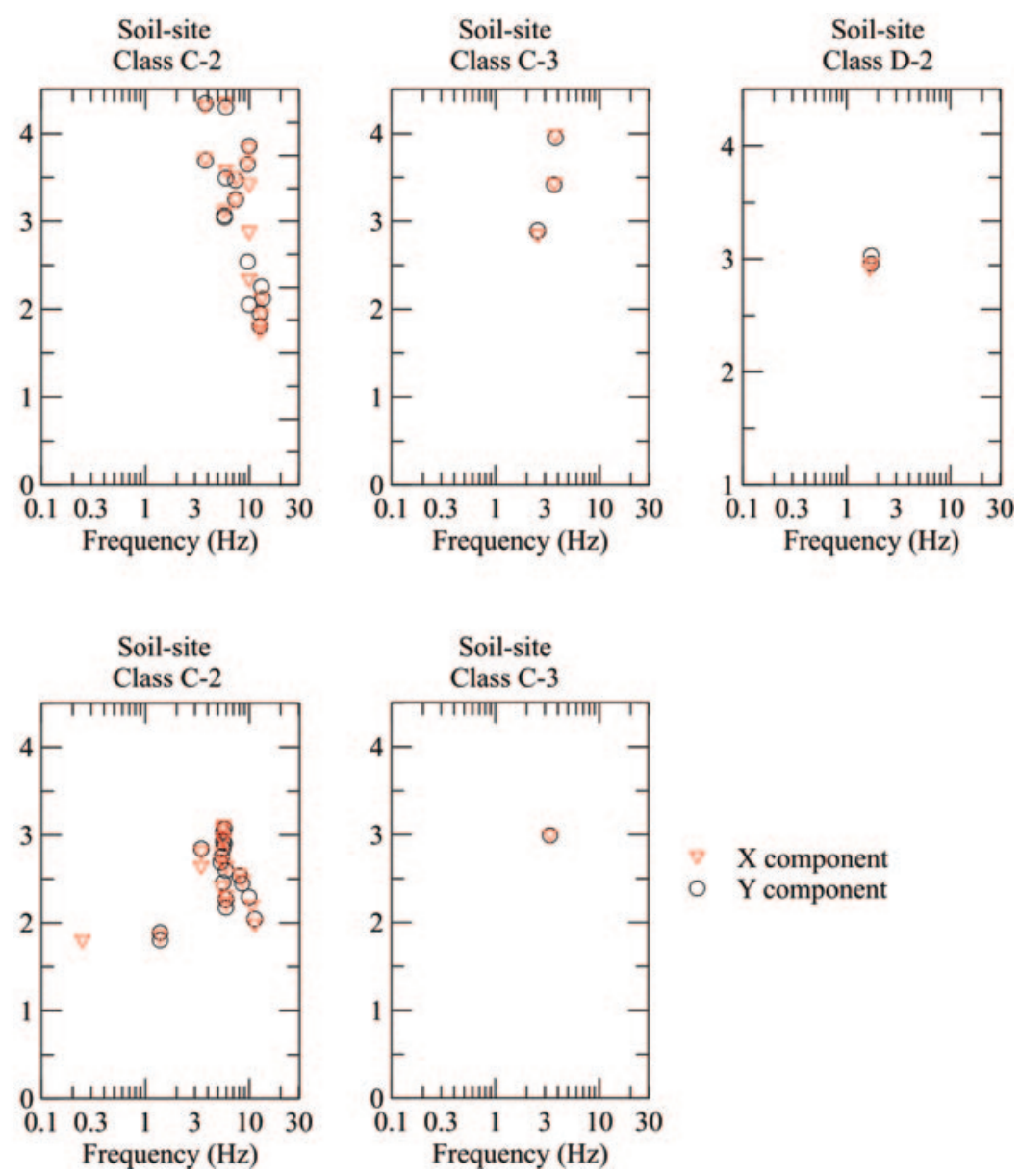

Figure 12. Summary of estimated seismic amplification factors for both horizontal acceleration components plotted against frequency (Hz) for all site class categories for (a) Tiryns and (b) Midea.

\subsection{Calculated surface ground-motions}

The surface ground-motions in both horizontal acceleration components differ significantly across soil types (Figure 13). At class C-1 sites, both surface horizontal accelerations components range between 0.08 to $0.1 \mathrm{~g}$ and 0.1 to $0.4 \mathrm{~g}$ for Tiryns and Midea, respectively (Figure 13). The inter-site discrepancy is due to the different regolith columns and epicentral distance. Class C-2 sites of Tiryns and Midea yield X-component and Y-component surface accelerations between 0.1 to $0.3 \mathrm{~g}$ and 0.1 to $0.7 \mathrm{~g}$, respectively. Class C-3 and D-2 sites outside Tiryns yield surface accelerations between 0.1 to $0.2 \mathrm{~g}$ in both horizontal acceleration components. The one class C-3 site at Midea yields a surface acceleration of $0.5 \mathrm{~g}$ in both horizontal components, due to the shortest epicentral distance and low shear strength of the regolith column (Figure 9). The surface ground-motions estimated with the empirical predictive relations of Margaris et al.[2002], Daciu and Tselentis [2007] and Skarlatoudis et al. [2003] agree with the low bound of the surface ground-motions calculated with the Equivalent-Linear site-specific response method (Figure 13). This is because the terms that take care of the local site effects and the regression method used to develop the empirical equations are based on the National Earthquake Hazard Reduction Program site classification scheme, which relies solely on the $\mathrm{v}_{\mathrm{S}}$ of the uppermost $30 \mathrm{~m}$ regardless of lithology type. Conversely, the EquivalentLinear site-specific response analysis honors $\mathrm{v}_{\mathrm{s}}$, lithology type, layer thickness and both the strain-dependent shear modulus reduction and the damping nature of the material. 
(a) Tiryns

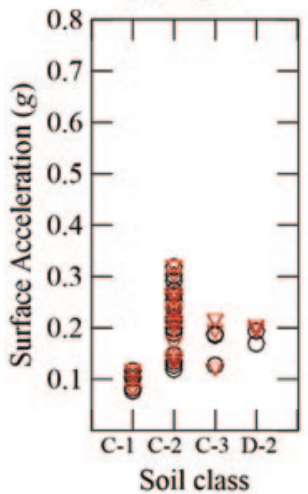

(c) Tiryns

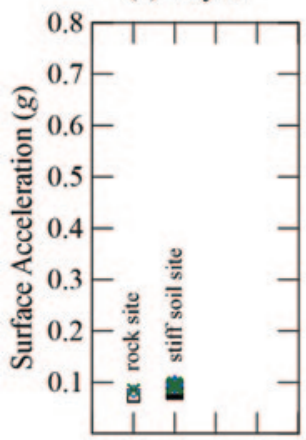

(b) Midea

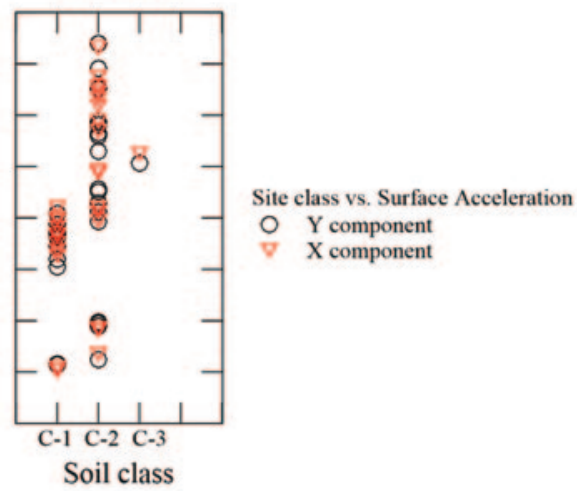

(d) Midea

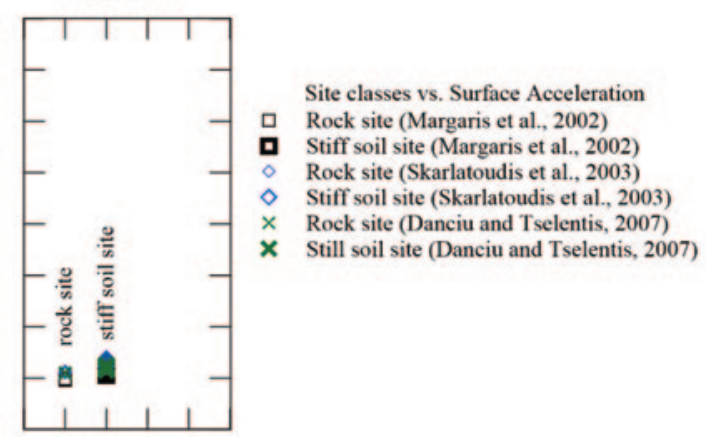

Figure 13. Summary of estimated maximum surface acceleration values for both acceleration components plotted against site class category for Tiryns and Midea calculated using the Equivalent-Linear site-response analysis (a and $\mathrm{b}$, respectively) and empirical ground-motion and attenuation relations (c and d, respectively).

\subsection{Calculated MMI}

The quantitatively estimated MMI (Figure 14) (resulting from the Equivalent-Linear site-specific response analysis) for both citadels differ noticeably despite both are within the near field area. The site class categories $\mathrm{C}$ 1, C-2, C-3, and D-2 of Tiryns yield MMI of VI, VI-VIII, VI-VII and VII, respectively, for either horizontal acceleration component (Figure 14). At Midea, site class categories C-1, C-2 and C-3 yield a MMI of VI-VIII, VI-IX and VIII-IX, respectively, also for either acceleration component. However, current archaeological knowledge does not indicate the existence of Mycenaean structures settled on class C-3 and D-2 sites outside Tiryns and C-2 and C-3 sites outside Midea. The MMI estimated with the empirical seismic ground-motions and attenuation equations are in agreement (Figure 14) with the MMI estimated with the surface ground-motions calculated with the Equivalent-Linear sitespecific response analysis.

\section{Discussion and interpretation}

Without both a comprehensive archaeoseismic assessment and ancient written records of a ca. 1190 BCE earthquake in the $\mathrm{AB}$, the causative role of the Mycenae fault seems as a rather convenient or circumstantial evidence. Within $\leqslant 150 \mathrm{~km}$ epicentral distance from Tiryns and Midea, there are numerous morphogenic faults of conspicuous outcrops, like the Mycenae fault, that are also potential ancient earthquake sources; however, these are unequivocally seismic active sources that have not received the same attention from Aegean archaeologists and geologists. The recent work of Hinojosa-Prieto [2016] and Hinzen et al. [2018] explore the role of some of these active seismogenic sources though other possible seismogenic sources remain to be explored [e.g. Caputo and 


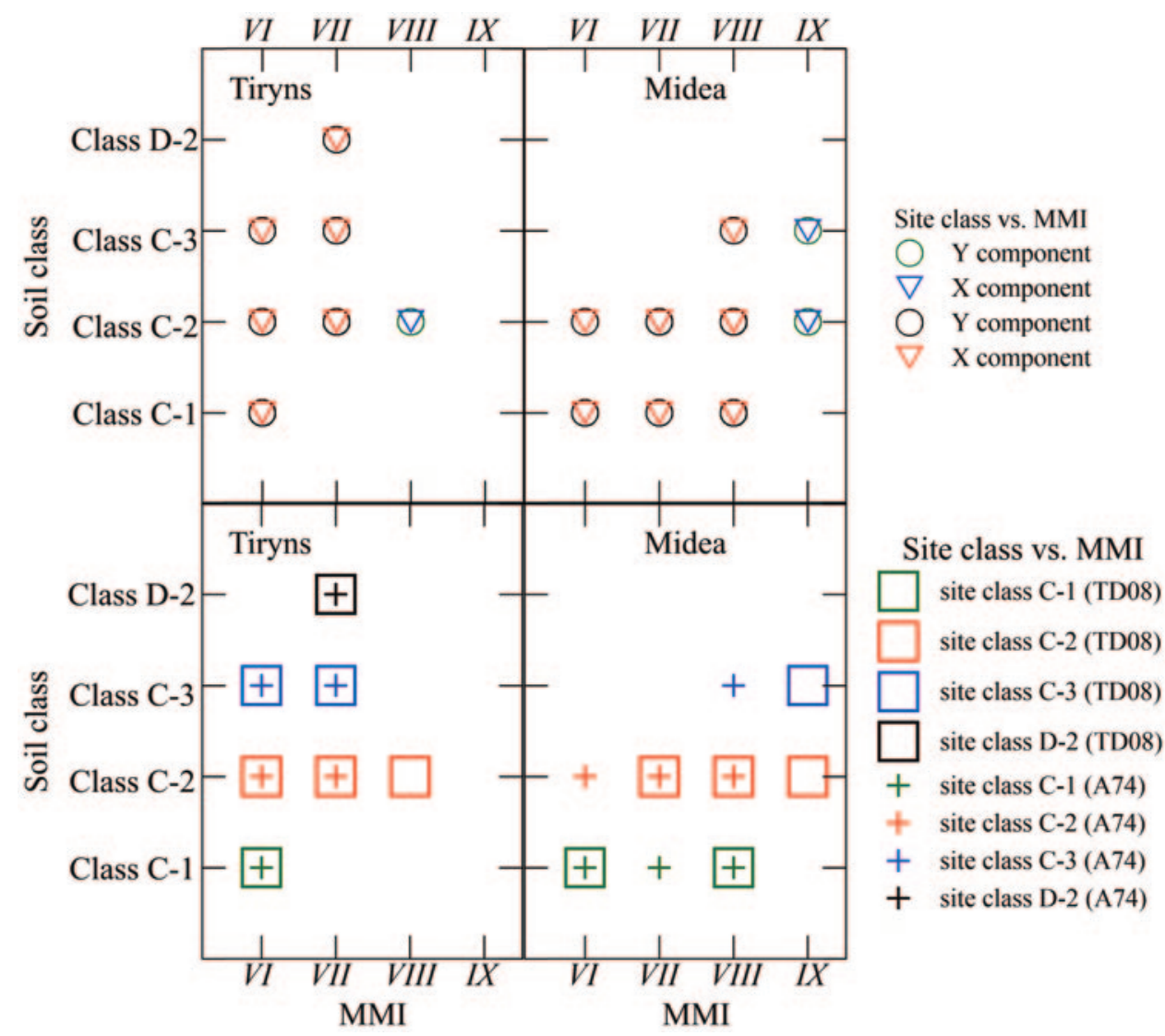

Figure 14. Estimated MMI values plotted against site class category for Tiryns and Midea calculated using the EquivalentLinear site-response analysis (a and b, respectively) and empirical MMI relations (c and d, respectively).

Pavlides, 2013]. Regardless of why the Mycenae fault was invoked as the causative fault for the presumed earthquake, and despite of its conspicuousness in outcrop and its proximity to Mycenean infrastructure, I adopted a quasideterministic approach in order to evaluate its potential influence. The approach is based on well-accepted numerical modeling techniques across various disciplines of seismology. Uncertainty might stem from the calculated synthetic seismograms despite they relied on carefully selected and vindicated input parameters found in the literature (see Table 2). This is a common challenge in numerical simulations of surface ground-motions, particularly for ancient earthquake scenarios. From the geological and geophysical points of view, the rupture of the archeologically assumed ca. 1190 BCE earthquake still remains rather speculative because the exposed fault scarp and its subsurface expression remain radiometrically undated and geophysically unconstrained, respectively. In addition, paleoseismic investigations for morphogenic earthquakes in the LBA and post-LBA are non-existent for the AG [cf. Hinojosa-Prieto, 2016; Hinzen et al., 2018]. Yet, the natural frequency (i.e. the oscillation frequency of a system in the absence of an oscillatory disturbing force, following Sheriff [2006] of Mycenaean buildings remains understudied. This leaves our understanding of soil-structure interactions of Mycenaean structures in its infancy. Hence, it is difficult to both assess the collapse process and establish if Mycenaean structures reached seismic resonance during ground shacking by past earthquakes.

Most of our current understanding about co-seismic rupture propagation is derived from inversion and interpretation of seismograms, laboratory experiments, or inferred from theoretical and numerical elastodynamic models [Di Toro et al., 2005]. In archaeoseismic research, the frequent absence of ancient earthquake records makes the estimation of earthquake source parameters difficult but at the same time promotes the use of numerical elastodynamic models to calculate synthetic seismograms with or without the role of local site effects [cf. Hinzen, 2005; Caputo et al., 2010; Hinzen et al., 2011, 2016, 2018]. The characterization of a seismogenic source based on available geologic fault data and empirical scaling relations of $\mathrm{M}_{\mathrm{W}}$ and $\mathrm{M}_{\mathrm{o}}$ are now common practice [Blaser et al., 2010; Haller and Basili, 2011; Mai et al., 2016]. However, the estimation of $\Delta \sigma$ of a not recorded ancient earthquake 


\section{Hector R. Hinojosa-Prieto}

is virtually an impossible task. Hence, the value of $\Delta \sigma$ has to be assumed on a rigorous selective criterion that must consider, at least, the focal mechanism, focal depth, and the tectonic setting. In the present quantitative archaeoseismic study, the implicit direction of rupture of the postulated ca. 1190 BCE earthquake implies that seismic energy was released towards the citadels. The study realistically estimates the probable $\mathrm{M}_{\mathrm{w}}$ of the assumed causative morphogenic earthquake with an empirical relation ( $\left.\mathrm{M}_{\mathrm{w}}-\mathrm{SRL}\right)$ ad hoc for Greek crustal normal faulting earthquakes from the Aegean Region. This is an advantage because the earthquakes used to derive the empirical relation share the same tectonic province and faulting mechanism as the postulated event. The adopted value for the seismic $\Delta \sigma$, required for the calculation of the synthetic seismograms, is appropriate for intraplate shallow crustal extensional earthquakes; selecting a lower value would not reflect the levels of crustal elastic deformations in an intraplate setting. Also, selecting a $\Delta \sigma$ value different than the median $\Delta \sigma$ would introduce a bias in the source energy. The role of the potential local site effects of the modeled ca. 1190 BCE earthquake is assessed using wellestablished numerical techniques in archaeoseismology, earthquake geology, and earthquake engineering. However, the 1D approach is not designed to handle topographic amplification effects; though these were addressed on the basis of a terrain slope analysis and properly estimated in a preceding publication [Hinzen et al., 2016]. These observables (i.e., $\mathrm{Mw}, \mathrm{Mo}$, and $\Delta \sigma$ ) were estimated in an unprecedented way. This has hampered a quantitative evaluation of the earthquake hypothesis and the assessment of the potential size of the mesoseismal area within the citadels and vicinities. The estimated $\mathrm{M}_{\mathrm{W}}=6.1$ is typical for a shallow morphogenic extensional earthquake in mainland Greece following Pavlides and Caputo [2004]. The clear morphogenic nature of the Mycenae fault and the here assumed epicentral distance ( $20 \mathrm{~km}$ to Tiryns) might imply strong motion in the near field.

The surface ground-motions estimated with the 1D Equivalent-Linear site-specific response analysis is of great importance because they honor the heterogeneity of different regolith columns (in the LBA) without generalizing their dynamic behavior over a large area. A 1D analysis considers the effects of soil response on one-dimensional (nearly vertical) wave propagation and assumes that the horizontally polarized shear-waves propagate vertically from the bedrock. Conversely, a 1D analysis cannot model slopping, irregular ground surfaces, sedimentary basin effects, and the inclusion of embedded structures. A site-specific ground response analysis is needed for sites with shallow outcropping bedrock conditions $(<30 \mathrm{~m})$, for hard rock sites with different reference rock conditions, for thin sections (5-15 m) of soil over hard rock, for thick sections ( $>30 \mathrm{~m}$ ) of critical soils sites conditions (i.e., F, E, and E/D soil classes), and for special and critical structures [Hashash, 2014]. All of the aforementioned conditions occur within the $A B$ and the limits of Tiryns and Midea. The simulated surface ground-motions are in general agreement with the surface ground-motions estimated with empirical peak ground-motion relation and the empirical ground-motion attenuation relations for Greek earthquakes; however, the last two approaches yield slightly lower estimates of surface ground-motion. The numerical discrepancy is attributed to the fact that the data used for the regression of the empirical equations do not represent the exact same site conditions seen at Tiryns and Midea. In other words, although they are for the same soil types classes, the actual regolith columns are different.

Qualitative archaeoseismic studies typically assign MMI $\geq$ VIII to toppled ancient man-made structures [e.g. Rapp, 1986; Stiros and Pytharouli, 2014]. The estimated MMI for C-1 sites on the Tiryns ridge yield MMI = VI, implying insufficient surface ground shaking to topple massive Mycenaean structures. On the other hand, C-1 sites on the Midea ridge yield $\mathrm{VI} \leq \mathrm{MMI} \leq \mathrm{VIII}$ due to the shorter epicentral distance and lower strength bedrock conditions. Collectively, the geotechnical site microzonation coupled with the local site effects assessment demonstrate that the citadels and the constructions on the sedimentary plain had the lower and higher seismic hazard, respectively. Yet, co-seismic evidence in Mycenaean structures excavated in the sedimentary plain is absent. The comprehensive archaeoseismic studies of Hinzen et al. [2018] and Hinojosa-Prieto [2016] also lead to the same remarks.

Hinzen et al. [2015] used seismological engineering models to topple Mycenaean terracotta figures and clay vessels found in a room within the Tiryns citadel. According to Kilian $[1978,1980]$, these artifacts were toppled by an earthquake in the post-palatial phase (LH IIIC Advanced). In the numerical simulations, the objects sat on a virtual bench and were excited by scaled strong ground motion records of instrumentally recorded Greek earthquakes ( $\left.3.4<\mathrm{M}_{\mathrm{w}}<6.4\right)$, but the simulated thrown position does not match the original find spots encountered by the excavators [Hinzen et al., 2015]; therefore, refuting the excavator's earthquake hypothesis. Hinzen et al. [2016] deduced earthquake site effects at Tiryns and Midea using ambient noise data recorded with passive seismic measurements. These workers found small site amplifications below a factor of 2 at frequencies between $2-10 \mathrm{~Hz}$ in the Tiryns citadel and amplifications of 4 to 6 at the soil sites around the citadel. At the Midea citadel, the topography results in ground-motion amplification of a factor of 2 to 3 at frequencies between 1 and $3 \mathrm{~Hz}$. The 
results of Hinzen et al. [2016] are for LBA surface conditions at the sites as well as present conditions, and are in general agreement with the present study.

In a comprehensive and holistic quantitative reassessment of the Mycenaean earthquake hypothesis, Hinzen et al. [2018] show that a destructive earthquake scenario in Tiryns and Midea during the Mycenaean palatial period is unlikely and that the reported structural damage can also be explained by non-seismic factors. They explored seismic site effects at both citadels using active and passive seismic measurements, a gravimetric survey, laser scanning, synthetic seismograms for several potential earthquake sources to estimate intensities of ground-motions inside and outside the citadels, and carried an analysis of individual damage descriptions and observations from the archaeological literature on which the Mycenean earthquake hypothesis is based on. Although they also modeled the Mycenae fault, it is not possible to do a direct comparison with my numerical modeling results because of the different choices in some input parameters in their numerical elastodynamic model; however, both results lead to the same interpretation.

Previous numerical modeling for the sedimentary plain suggests that the cohesive soils in the $A B$ are prone to earthquake-induced soil-liquefaction in response to nearby shallow crustal earthquakes [Karastathis et al., 2010]. Putting such study into perspective, if soil-liquefaction happened outside Tiryns and Midea during the Mycenaean palatial period in response to the assumed ca. 1190 BCE earthquake, the cohesive soils around Tiryns could have liquefied and Mycenaean structures settled on these soils would have likely been affected. Nevertheless, neither archaeological nor geoarchaeological excavations show earthquake-related damage to ancient structures, geological evidence of soil-liquefaction, or soil deformation.

\section{Conclusions}

Archaeologically estimated macroseismic intensity has been a proxy to back calculate the strength of past earthquakes [i.e. Rapp, 1986; Stiros and Pytharouli, 2014; Gorduño-Monrroy, 2016], but it often lacks the consideration of the geologic and topographic site conditions and provides little clues about the level of surface ground-motions and the mesoseismal area. Moreover, archaeoseismological observations are often based on a limited part of the mesoseismal area, poorly constrained dated earthquakes, and both poorly documented and ambiguous structural damage [Hinzen et al., 2015]. The combination of these factors hampers an inter-site correlation of ancient earthquake damage, leading to inaccurate estimates of the strength of past earthquakes to ancient structures [Galadini et al., 2006]. Because of the local site effects, earthquakes do not need to be of large magnitude and have a short epicentral distance to caused structural damage. A moderate-to-strong earthquake influenced by local site effects and a long epicentral distance can cause significant structural damage. Hence, neglecting the role of local site effects in archaeoseismological research leads to an underestimated or overestimated size of an ancient earthquake and inaccurate estimates of ancient surface ground-motions. The quantitative assessment of local site effects in archaeoseismological research is emerging [see Caputo et al., 2010; Hinzen et al., 2011, 2015, 2016, 2018; Hinojosa-Prieto, 2016)] and requires a multimethod approach. It is important not to solely rely on estimated MMI derived from qualitative archaeological excavation data and/or field observations (i.e. descriptive) to estimate the size and strength of an ancient causative earthquake, its related surface ground-motion, and the mesoseismal area. The present study demonstrates that ancient local site effects can be estimated in a quantitative way at previously excavated or unexcavated archaeological sites, as long as the site conditions are well-understood.

The plausibility of the earthquake hypothesis has been quantitatively tested via forward numerical modeling of both the earthquake source parameters of the assumed causative ca. 1190 BCE Mycenae Fault and its possible local site effects. The modeling results strongly suggest that seismic loading would have been much lower at the Tiryns' bedrock than at Midea's bedrock. Contrarywise, the soils around the citadels would have undergone even higher levels of seismic amplification, surface ground-shaking, and earthquake intensity leading to a town-wide devastation pattern, which is not seen in the ample archaeological record of the $A B$ that exceeds 100 years. Conclusive evidence of earthquake activity in and since the end of the LBA within the $\mathrm{AB}$ is absent or remains undiscovered. The insights gained from the present quantitative study refute the archaeological idea of synchronized co-seismic damage at the adjacent Mycenaean citadels of Tiryns and Midea by the activation of the local Mycenae fault during the end of the LBA. The formerly postulated damage to Mycenaean structures at these citadels may not represent physical evidence 


\section{Hector R. Hinojosa-Prieto}

of co-seismic damage. The quasi-deterministic approach developed in this paper is also applicable to other Greek faults to rule out candidate earthquake sources as well as to other archaeological sites worldwide.

Acknowledgements. This work is part of the HERACLES project which was financed by the Fritz Thyssen Foundation (Az.10.11.2.39) and the Gerda Henkel Foundation (AZ 25/F/11). Additional funding came from the Graduate School of Geosciences (GSGS) Fellowship Grant 2016A of the University of Cologne, Germany that I obtained during my doctoral studies at the University of Cologne. Constructive reviews by Klaus G. Hinzen, Ursula Damm-Meinhardt, Karl Kibler, George H. Davis, and Ricardo Caputo improved the quality of the original manuscript. Thank you to Claus Fleischer, Gregor Schweppe, Klaus Webber, Sharon K. Reamer, T. Kalytta, S. Falter, N. Haaf, T. Koch, S. Voigt, Iris Schwellenbach, Eberhard Zannger, E. Seferou, Pantelis Soupious, S. Prillwitz,A. Papadimitriou, and K. Demakopoulou for support during both field and laboratory work. Thank you to the Editor Andrea Bizzarri and the manager of publication production Anna Grazia Chiodetti.

\section{References}

Aki, K. (1993). Local site effects on weak and strong ground motion, Tectonophysics, 218, 93-111.

Allmann, B. P. and P. M. Shearer (2009). Global variations of stress-drop for moderate to large earthquakes, J. Geophys. Res. 114, 1-22.

Al-Tarazi, E. A. and A. M. Korjenkov (2007). Archaeoseismological investigation of the ancient Ayla site in the city of Aqaba, Jordan, Nat. Hazards, doi 10.1007/s11069-006-9045-6

Åström, P. and K. Demakopoulou (1996). Signs of an earthquake at Midea?, in Archaeoseismology Stiros, S. and Jones, R. E. (Editors), Fitch Laboratory Occasional Paper No. 7, Athens, 37-40.

Ambraseys, N. N. (1974). The correlation of intensity with ground-motions, in Advancements in Engineering Seismology in Europe, Trieste.

Blaser, L., F. Krüger, M. Ohrnberger and F. Scherbaum (2010). Scaling relations of earthquake source parameter estimates with special focus on subduction environment, Bull. Seism. Soc. Am., 100, 2914-2926.

Boore, D. M. (2004). Can site response be predicted?, J. Earthq. Engi., 8, 1-41.

Caputo R. (2005): Ground effects of large morphogenic earthquakes. J. Geodyn., 40(2-3), 113-118, doi:10.1016/j.jog.2005.07.001.

Caputo, R., K.-G. Hinzen, D. Liberatore, S. Schreiber, B. Helly and A. Tziafalias (2010). Quantitative archaeoseismological investigation of the Great Theatre of Larissa, Greece, Bull. Earthq. Engi., 9, 347-366.

Caputo R. and Pavlides S. (2013). The Greek Database of Seismogenic Sources (GreDaSS), version 2.0.0: A compilation of potential seismogenic sources $(\mathrm{Mw}>5.5)$ in the Aegean Region. http://gredass.unife.it, doi:10.15160/unife/gredass/0200

Caputo M. and Caputo R. (2016). Density distribution functions of faults and scaling relations, International Journal of Advanced Geosciences, 4, 42-53.

Courboulex, F., M. Vallée, M. Causse and A. Chounet (2016). Stress-Drop Variability of Shallow Earthquakes Extracted from a Global Database of Source Time Functions, Seism. Res. Letts., 87, 1-7.

Danciu, L. and G-A. Tselentis (2007). Engineering Ground-Motion Parameters Attenuation Relationships for Greece, Bull. Seism. Soc. Am., 97 (1B), 162-183.

Demakopoulou, K. (1995). Mycenaean citadels: recent excavations on the acropolis of Midea in the Argolid, Bulletin of the Institute of Classical Studies, 40, 151-176.

Demakopoulou, K. (2012). The Mycenaean acropolis of Midea. Archaeological Receipts Fund Publications Department, Athens, Greece.

Denolle, M. A., E. M. Dunham, G. A. Prieto and G. C. Beroza (2014). Strong Ground Motion Prediction Using Virtual Earthquakes, Science, 343, 399-403.

Di Toro, G., S. Nielsen and G. Pennacchioni (2005). Earthquake rupture dynamics frozen in exhumed ancient faults, Nature, 436, 1009-1012.

EN 1998-5 (2004) (English). Eurocode 8 (EC8): Design of structures for earthquake resistance - Part 5: Foundations, retaining structures and geotechnical aspects [Authority: The European Union Per Regulation 305/2011, Directive 98/34/EC, Directive 2004/18/EC]

Ferraro, A., S. Grasso and M. R. Massimino (2018). Site Effects Evaluation in Catina (Italy) by means of 1-D Numerical 
Analysis, Ann. Geophys., 61 (2), SE224, doi 10.4401/ag-7708.

Gaki-Papanastassiou, K., D. Papanastassiou and H. Maroukian (1996). Geomorphic and archaeological-historical evidence for past earthquakes in Greece, Annali di Geofisica. XXXIX, 589-601.

Galadini, F., K.-G. Hinzen and S. Stiros (2006). Archaeoseismology: methodological issues and procedure, J. Seism., 10, 395-414.

Georgiou, Ch. and D. Galanakis (2010). Neotectonic study of urban and suburban Nafplion area (Argolida-Greece), Bull. Geol. Soc. Greece, XLIII, 1428-1437.

Goebel, T. H. W., E. Hauksson, P. M. Shearer and J. P. Ampuero (2015). Stress-drop heterogeneity within tectonically complex regions: a case study of San Gorgonio Pass, southern California, Geophys. J. Intl., 202, 514-528.

Goldsworthy, M., J. Jackson and J. Haines (2002). The continuity of active faults systems in Greece, Geophys. J. Intl., 148, 596-618.

Gorduño-Monrroy, V. H. (2016). Una Propuesta de Escala de Intensidad Sísmica Obtenida del Códice Náhuatl Telleriano Remensis, Arqueología Iberoamericana, 31, 9-19.

Haller, K. M., and R. Basili (2011). Developing Seismogenic Source Models Based on Geologic Fault Data, Seism. Res. Letts., 82, 519-525.

Hanks, T. C., and H. Kanamori (1979). A Moment Magnitude Scale, J. Geophys. Res., 84, 2348-2350.

Hatzfeld, D., G. Pedotti, P. Hatzidimitriou, D. Panagiotopoulos, M. Scordilis, I. Drakopoulos, K. Makropoulos, N. Delibasis, I. Latousakis, J. Baskoutas and M. Frogneux (1989). The Hellenic subduction zone beneath the Peloponnesus: first results of a microearthquake study, Earth Planet. Sci. Letts., 93, 283-291.

Hatzfeld, D., M. Besnard, K. Markopoilos, N. Voulgaris, V. Kosuskouna, P. Hatzidimitriou, D. Panagiotopoulos, G. Karakaisis, A. Deschamps and H. Lyon-Caen (1993). Subcrustal microearthquake seismicity and fault plane solutions beneath the Hellenic arc, J. Geophys. Res., 98, 9861-9870.

Hashash, Y. A. (2014). Current issues in evaluation of seismic site effects. The 18th Great Lakes Geotechnical and Geoenvironmental Conference (GLGGC), and The 2014 Chicago Geotechnical Lecture Series Geotechnical Earthquake Engineering. 02 May, 2014.

Hailemikael, S., G. Milana, F. Cara, M. Vassallo, M. Pischiutta, S. Amoroso, P. Bordoni, L. Cantore, G. Di Giulio, D. Di Naccio, D. Famiani, A. Mercuri (2017). Sub-surface characterization of the Amphiteatrum Flavium area (Rome, Italy) through single-station ambient vibration measurements, Ann. Geophys., 60, 4, S0438, doi:10.4401/ag7359

Helly, B. and A. Rideaud (2016). Ten years of archaeoseismological research in Armenia (2004-2013), Quaternary Intl, 395, 216-232.

Hinojosa-Prieto, H. R. (2016). Local Site Effects in Archaeoseismology: Examples from the Mycenaean Citadels of Tiryns and Midea (Argive Basin, Peloponnese, Greece). PhD thesis, Universität zu Köln, 244. http://kups.ub.unikoeln.de/id/eprint/6650

Hinojosa-Prieto, H. R. and K.-G. Hinzen (2015). Seismic velocity model and near-surface geology at Mycenaean Tiryns, Argive Basin, Peloponnese, Greece, Near Surf. Geophys., 13, 103-113.

Hinzen, K.-G. (2005). The use of engineering seismological models to interpret Archaeoseismological findings in Tolbiacum, Germany: A case study, Bull. Seism. Soc. Am., 95, 521-539.

Hinzen, K.-G., C. Fleischer, S. K. Reamer, S. Schreiber, S. Schütte and B. Yeril (2011). Quantitative methods in archaeoseismology, Quaternary Intl, 242, 31-41.

Hinzen, K.-G., C. Fleischer, H. Hinojosa, J. Maran, U. Meinhardt, S. K Reamer, G. Schweppe and J. Tzislakis (2013). The Mycenaean palace of Tiryns, elements of a comprehensive archaeoseismic study, Seism. Res. Letts., 84, 350.

Hinzen, K.-G., M.Vetters, T. Kalytta, S. K. Reamer and U. Damm-Meinhardt (2015). Testing

the response of Mycenaean terracotta figures and vessels to earthquake ground-motions, Geoarchaeology: An Intl. J., 30, 1-18.

Hinzen, K.-G., H. R. Hinojosa-Prieto and T. Kalytta (2016). Site Effects in Archaeoseismic Studies at Mycenaean Tiryns and Midea, Seism. Res. Letts., 87, 1-15.

Hinzen, K.-G., J. Maran, H. Hinojosa-Prieto, U. Damm-Meinhardt, S. K. Reamer, J. Tzislakis, K. Kemna, G. Schweppe, C. Fleischer and K. Demakopoulou (2018). Reassessing the Mycenaean Earthquake Hypothesis: Results of the HERACLES Project from Tiryns and Midea, Greece, Bull. Seism. Soc. Am., doi.org/10.1785/0120170348.

Karastathis, V. K., P. Karmis, T. Novikova, Z. Roumelioti, E. Gerolymatou, D. Papanastassiou, S. Lakopoulos, P. Tsombos and G. A. Papadopoulos (2010). The contribution to geophysical techniques to site characterization 


\section{Hector R. Hinojosa-Prieto}

and liquefaction risk assessment: case study of Nafplion city, Greece, J. Appl. Geophys., 72, 194-211.

Kilian, K. (1978). Ausgrabungen in Tiryns 1976. Bericht zu den Grabungen, Archäologischer Anzeiger, 1978, 449-470.

Kilian, K. (1980). Zum Ende der mykenischen Epoche in der Argolis, Jahrbuch des Römisch-Germanischen Zentralmuseums, 27, 166-195.

Kilian, K. (1988). Mycenaeans up to date, trends and changes in recent research, in Problems in Greek Prehistory French, E. B. and K. A. Wardle (Editors), Bristol Classical Press, Bristol, 115-152.

Kilian, K. (1996). Earthquakes and archaeological context at 13th century BC Tiryns, in Archaeoseismology Stiros, S., and R. E. Jones, (Editors), Fitch Laboratory Occasional Paper 7, Athens, 63-68.

Konstantinou, K. I. (2014). Moment Magnitude-Rupture Area Scaling and Stress-drop Variations for Earthquakes in the Mediterranean Region, Bull. Seism. Soc. Am., 104, 1-9.

Korjenkova, A. M. and E. Mazorc (2013). The Features of the Earthquake Damage Patterns of Ancient City Ruins in the Negev Desert, Israel, Geotechn., 47, 52-65.

Maggi, A., J. A. Jackson, D. McKenzie and K. Priestley (2000). Earthquake focal depths, effective elastic thickness, and the strength of the continental lithosphere, Geology, 28, 495-498.

Mai, P. M., P. Shearer, J.-P. Ampuero and T. Lay (2016). Standards for Documenting Finite-Fault Earthquake Rupture Models, Seism. Res. Letts., 87, 712-718.

Maran, J. (2004). Architektonische innovation im spätmykenischen Tiryns-Lokale bauprogramme und fremde kultureinflüsse, in Althellenische Technologie und Technik Kyriatsoulis, A. (Editor), Ohlstadt, Weilheim, 261286.

Maran, J. (2010). Tiryns, in The Oxford Handbook of the Bronze Age Aegean (ca. 3000-1000 BC) Cline, E. H. (Editor), Oxford University Press, Inc., New York, 722-736.

Margaris, B., C. Papazachos, Ch. Papaioannou, N. Theodulidis, N. Kalogeras and Skarlatoudis (2002). Ground motion attenuation relations for shallow earthquakes in Greece, $12^{\text {th }}$ European conference on Earthquake engineering. Paper Reference 385.

Maroukian, H., K. Gaki-Papanastassiou and D. Papanastassiou (1996). Geomorphologic-seismotectonic observations in relation to the catastrophes at Mycenae, in Archaeoseismology Stiros, S. and R. E. Jones (Editors), Fitch Laboratory Occasional Paper 7, Athens, 189-194.

Minos-Minopoulos, D., K. Pavlopoulos, G. Apostolopoulos, E. Lekkas, D. Dominey-Howes (2015). Liquefaction features at an archaeological site: Investigations of past earthquake events at the Early Christian Basilica, Ancient Lechaion Harbour, Corinth, Greece, Tectonophysics, 658, 74-90

Panzera, F., G. Lombardo, S. D’Amico and P. Galea (2013). Chapter 5: Speedy Techniques to Evaluate Seismic Site Effects in Particular Geomorphologic Conditions: Faults, Cavities, Landslides and Topographic Irregularities. http://dx.doi.org/10.5772/55439

Papadimitriou, A. (2001). Tiryns: A guide to its history and archaeology, Hesperos editions, Athens, Greece.

Papanastassiou, D., D. H. Maroukian and K. Gaki-Papanastassiou (1993). Morphotectonic and archaeological observations in the eastern Argive plain (eastern Peloponnese, Greece), and their palaeoseismological implications, Zeitschrift für Geomorphologie Supplement Volume, 94, 95-105.

Papanikolaou, D., G. Chronis and C. Metaxas (1994). Neotectonic structure of the Argolic gulf, Bull. Geol. Soc. Greece, 30, 305-316.

Papastamatiou, J., D. Vetoulis, A. Tataris, G. Christodoulou, J. Bornova, N. Lalechos and G. Kounis (1960). Argos sheet in scale 1:50,000, geological map of Greece. Institute for Geology and Subsurface Research, Athens, Greece.

Pavlides, S. and R. Caputo (2004). Magnitudes versus faults' surface parameters: quantitative relationships from the Aegean region, Tectonophysics, 380, 159-188.

Rapp, G. Jr. (1986). Assessing archaeological evidence for seismic catastrophes, Geoarchaeology: An Intl J., 1, 365379.

Robinson, D., T. Dhu and J. Schneider (2006). SUA: a computer program to compute regolith site-response and estimate uncertainty for probabilistic seismic hazard analyses, Compu. \& Geosci., 32, 109-123.

Rodríguez-Marek, A., J. D. Bray and N. A. Abrahamson (2001). An empirical geotechnical seismic site response procedure, Earthq. Spectra, 17, 65-87.

Şafak, E. (2001). Local site effects and dynamic soil behavior, Soil Dyn. Earthq. Eng., 21, 453-458.

Satoh T. and A. Okazaki (2016). Relation Between Stress-drops and Depths of Strong Motion Generation Areas Based on Previous Broadband Source Models for Crustal Earthquakes in Japan, in Earthquakes, Tsunamis and Nuclear 
Risks Kamae K. (Editor), Springer, Tokyo, 77-85.

Savvaidis, A. S., C. B. Papazachos and P. M. Hatzidimitriou (1998). Site effect estimation based on source and path modeling of macroseismic intensities in the area of Greece, Eu. Earthq. Eng., 12, 18-28.

Schliemann, H. (1886). Tiryns: Der prähistorische Palast der Könige von Tiryns. F. A. Brockhaus, Leipzig, Germany. Shearer, P. M., G. A. Prieto and E. Hauksson (2006). Comprehensive analysis of earthquake source spectra in southern California, J. Geophys. Res., 111, 1-21.

Sheriff, R. E. (2006). Encyclopedic Dictionary of Applied Geophysics, Society of Exploration Geophysics, Oklahoma. Sintubin, M. and I. S. Stewart (2008). A Logical Methodology for Archaeoseismology: A Proof of Concept at the Archaeological Site of Sagalassos, Southwest Turkey, Bull. Seism. Soc. Am., 98, 2209-2230, doi:10.1785/0120070178

Skarlatoudis, A. A., C. B. Papazachos, B. Margaris, N. Theodulidis, Ch. Papaioannou, I. Kalogeras, E, M. Scordilis and V. Karakostas (2003). Empirical Peak Ground-Motion Predictive Relations for Shallow Earthquakes in Greece, Bull. Seism. Soc. Am., 93, 2591-2603.

Somerville, P. and Y. Moriwaki (2003). Seismic hazard and risk assessment in engineering

Practice, in International Handbook of Earthquake \& Engineering Seismology: Part B William, H. K. L., H. Kanamori, P. C. Jennings and C. Kisslinger (Editors), International Association of Seismology and Physics of the Earth's Interior, 1065-1080.

Steidl, J. H., A. G. Tumarkin and R. J. Archuleta (1996). What is a reference site?, Bull. Seism. Soc. Am., 86, 1733-1748.

Stiros, S. C. and S. I. Pytharouli (2014). Archaeological evidence for a destructive earthquake in Patras, Greece, J. Seism., 18, 687-693.

Tataris, A., G. Kallergis, G. Kounis, G. Bizon and G. Christodoulou (1970). Nafplion sheet in scale 1:50,000, Geological map of Greece. Institute for Geology and Subsurface Research, Athens, Greece.

Tselentis, G.-A. and L. Danciu (2008). Empirical Relationships between Modified Mercalli Intensity and Engineering Ground-Motion Parameters in Greece, Bull. Seism. Soc. Am., 98, 1863-1875.

van Andel, T. H., E. Zangger and C. Perissoratis (1990). Quaternary transgressive/regressive cycles in the gulf of Argos, Greece, Quaternary Res., 34, 317-329.

van Andel, T. H., C. Perissoratis and T. Rondoyanni (1993). Quaternary tectonics of the Argolikos gulf and adjacent basins, Greece, J. Geol. Soc. London, 150, 529-539.

Walberg, G. (2001). Midea excavations on the acropolis of Midea. Results of the Greek-Swedish excavations, The Classical Review, New Series. 51, 355-357.

Wang, R. (1999). A simple orthonormalization method for stable and efficient computation of Green's functions, Bull. the Seism. Soc. Am., 89, 733-741.

Wells, D. L. and K. J. Coppersmith (1994). New empirical relationships among magnitude, rupture length, rupture width, rupture area, and surface displacement, Bull. Seism. Soc. Am, 84, 974-1002.

Zangger, E. (1993). The geoarchaeology of the Argolid. Deutsches Archäologisches Institut Athens: Gebr. Mann Verlag Berlin, 153.

CORRESPONDING AUTHOR: Hector R. HINOJOSA-PRIETO,

Earthquake Geology and Archaeoseismology,

Institute for Geology and Mineralogy, Cologne University,

Bensberg Seismological Station,

Vinzenz-Pallotti-Str. 26, 51429, Bergisch Gladbach, Germany,

and Cordillera Geo-Services,

LLC 1723 Warwick Way, Cedar Park, Texas 78613, USA,

e-mail: hector.hinojosa@cordillerageo.services

(c) 2020 the Istituto Nazionale di Geofisica e Vulcanologia.

All rights reserved 